\title{
Redox Interconversion between Cobalt(III) Thiolate and Cobalt(II) Disulfide Compounds
}

\author{
Feng Jiang, ${ }^{\dagger}$ Maxime A. Siegler, ${ }^{\ddagger}$ Xiaobo Sun, ${ }^{\S}$ Lin Jiang, ${ }^{\dagger}$ Célia Fonseca Guerra, ${ }^{*}, \dagger, \S_{\odot}$
} and Elisabeth Bouwman* ${ }^{\dagger} \dagger$

${ }^{\dagger}$ Leiden Institute of Chemistry, Gorlaeus Laboratories, Leiden University, P.O. Box 9502, 2300 RA Leiden, The Netherlands

${ }^{\ddagger}$ Department of Chemistry, Johns Hopkins University, 3400 North Charles Street, Baltimore, Maryland 21218, United States

${ }^{\S}$ Department of Theoretical Chemistry, Amsterdam Center for Multiscale Modeling (ACMM), Vrije Universiteit Amsterdam, De Boelelaan 1083, 1081 HV Amsterdam, The Netherlands

\section{Supporting Information}

ABSTRACT: The redox interconversion between Co(III) thiolate and Co(II) disulfide compounds has been investigated experimentally and computationally. Reactions of cobalt(II) salts with disulfide ligand $\mathrm{L}^{1} \mathrm{SSL}^{1}\left(\mathrm{~L}^{1} \mathrm{SSL}^{1}=\right.$ di-2-(bis $(2$ pyridylmethyl)amino)-ethyl disulfide) result in the formation of either the high-spin cobalt(II) disulfide compound $\left[\mathrm{Co}_{2}{ }_{2}\left(\mathrm{~L}^{1} \mathrm{SSL}^{1}\right) \mathrm{Cl}_{4}\right]$ or a low-spin, octahedral cobalt(III) thiolate compound, such as $\left[\mathrm{Co}^{\mathrm{III}}\left(\mathrm{L}^{1} \mathrm{~S}\right)(\mathrm{MeCN})_{2}\right]\left(\mathrm{BF}_{4}\right)_{2}$. Addition of thiocyanate anions to a solution containing the latter compound yielded crystals of $\left[\mathrm{Co}^{\mathrm{III}}\left(\mathrm{L}^{1} \mathrm{~S}\right)(\mathrm{NCS})_{2}\right]$. The addition of chloride ions to a solution of $\left[\mathrm{Co}^{\mathrm{III}}\left(\mathrm{L}^{1} \mathrm{~S}\right)\right.$ $\left.(\mathrm{MeCN})_{2}\right]\left(\mathrm{BF}_{4}\right)_{2}$ in acetonitrile results in conversion of the cobalt(III) thiolate compound to the cobalt(II) disulfide compound $\left[\mathrm{Co}_{2}{ }_{2}\left(\mathrm{~L}^{1} \mathrm{SSL}^{1}\right) \mathrm{Cl}_{4}\right]$, as monitored with UV-vis spectroscopy; subsequent addition of $\mathrm{AgBF}_{4}$ regenerates the $\mathrm{Co}$ (III) compound. Computational studies show that exchange by a chloride anion of the coordinated acetonitrile molecule or thiocyanate anion in compounds $\left[\mathrm{Co}^{\mathrm{III}}\left(\mathrm{L}^{1} \mathrm{~S}\right)\right.$ -

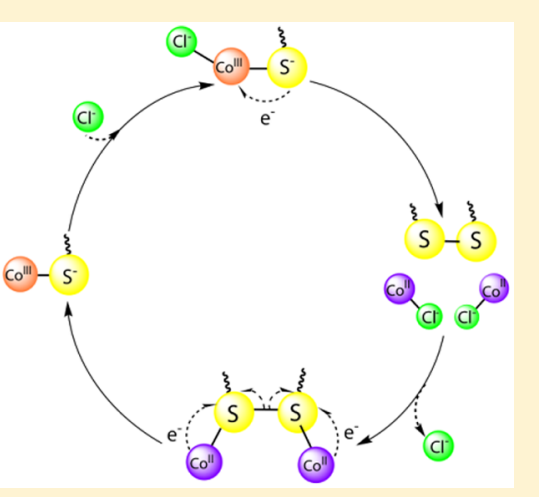
$\left.(\mathrm{MeCN})_{2}\right]^{2+}$ and $\left[\mathrm{Co}^{\mathrm{III}}\left(\mathrm{L}^{1} \mathrm{~S}\right)(\mathrm{NCS})_{2}\right]$ induces a change in the character of the highest occupied molecular orbitals, showing a decrease of the contribution of the $\mathrm{p}$ orbital on sulfur and an increase of the $\mathrm{d}$ orbital on cobalt. As a comparison, the synthesis of iron compounds was undertaken. X-ray crystallography revealed that structure of the dinuclear iron(II) disulfide compound $\left[\mathrm{Fe}_{2}^{\mathrm{II}}\left(\mathrm{L}^{1} \mathrm{SSL}^{1}\right) \mathrm{Cl}_{4}\right]$ is different from that of cobalt(II) compound $\left[\mathrm{Co}_{2}^{\mathrm{II}}\left(\mathrm{L}^{1} \mathrm{SSL}^{1}\right) \mathrm{Cl}_{4}\right]$. In contrast to cobalt, reaction of ligand $\mathrm{L}^{1} \mathrm{SSL}^{1}$ with $\left[\mathrm{Fe}(\mathrm{MeCN})_{6}\right]\left(\mathrm{BF}_{4}\right)_{2}$ did not yield the expected $\mathrm{Fe}(\mathrm{III})$ thiolate compound. This work is an unprecedented example of redox interconversion between a high-spin Co(II) disulfide compound and a low-spin Co(III) thiolate compound triggered by the nature of the anion.

\section{INTRODUCTION}

Sulfur-containing metalloenzymes are ubiquitous in biological systems and play fundamental roles in electron-transfer reactions including oxygen transport, nitrite reduction, and the synthesis of neurotransmitters. ${ }^{1-4}$ A small number of these metalloenzymes involve thiolate/disulfide interconversion, related to the uptake or release of the metal ions. ${ }^{5-7}$ For instance, copper delivery to the $\mathrm{Cu}_{\mathrm{A}}$ site of cytochrome $\mathrm{c}$ oxidase $(\mathrm{CcO})$ involves Sco proteins, and the potential operation principle has been suggested to involve thiolate/ disulfide interconversion of two cysteine residues. ${ }^{8,9}$ Metallothionein $\mathrm{Zn}_{7} \mathrm{MT}-3$ has been reported to exchange its $\mathrm{Zn}$ (II) ions with $\mathrm{Cu}(\mathrm{II})$ centers of amyloid- $\beta$ peptide $(\mathrm{CuA} \beta)$. During this exchange four $\mathrm{Cu}(\mathrm{II})$ ions are reduced to $\mathrm{Cu}(\mathrm{I})$ by four cysteine thiolate groups in MT-3 with the formation of two disulfide bonds. ${ }^{10,11}$ The essence of the thiolate to disulfide oxidation of cysteines is an electron that shuttles from the cysteine thiolate sulfur to the metal ion in a high oxidation state, after which a disulfide is formed and a geometry change takes place of the reduced metal center in the active site.
However, to the best of our knowledge, the exact mechanism is not well understood of this interconversion in biological systems. ${ }^{1}$ In the last decades, this phenomenon inspired coordination chemists to synthesize metal thiolate compounds and study their redox interconversion. Since the first publication of a mixed-valence $\left(\mathrm{Cu}^{\mathrm{II}} \mathrm{Cu}^{\mathrm{I}}\right)$ thiolate compound, ${ }^{12,13}$ considerable efforts were put in the synthesis and characterization of $\mathrm{Cu}$ (II) thiolate compounds, and the investigation of their redox interconversion to the isomeric $\mathrm{Cu}(\mathrm{I})$ disulfide compounds. ${ }^{14-20}$ The chloride-dependent redox interconversion between $\mathrm{Cu}(\mathrm{II})$ thiolate and $\mathrm{Cu}(\mathrm{I})$ disulfide compounds was first reported by Itoh et al., ${ }^{20}$ followed later by the group of Henkel. ${ }^{15}$ In recent years, our group further investigated the effect of temperature and solvents on the thiolate/disulfide redox interconversion of copper compounds. ${ }^{18}$ Up until now, several triggers have been reported to influence the copper thiolate/disulfide redox

Received: March 7, 2018

Published: July 19, 2018 
interconversion like the addition of halide ions ${ }^{15,20}$ or protons, ${ }^{16,19}$ as well as changes in temperature, ${ }^{18}$ and the polarity of solvents. ${ }^{18}$ In addition, also ligand structure has a distinct influence on the redox interconversion (Scheme 1). ${ }^{14,21}$

Scheme 1. Reported Redox Interconversion between Copper(II) Thiolate and Copper(I) Disulfide Compounds Triggered by Different Reaction Conditions $\left(R^{1}, R^{2}=H\right.$, $\mathrm{CH}_{3}$ )

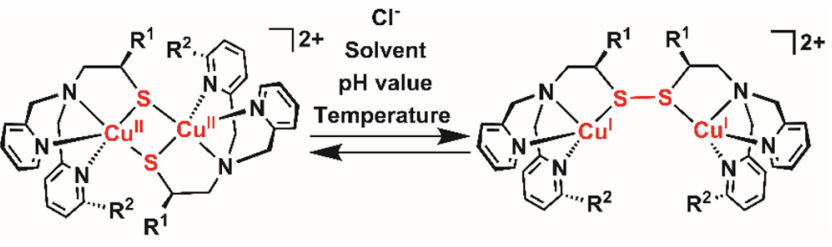

As electron-transfer reactions also take place in metalloenzymes containing metal centers other than copper, ${ }^{22,23}$ all of this impressive work inspired us to study whether the thiolate/disulfide redox interconversion could occur for complexes of metal ions like cobalt or iron. Duboc et al. reported the electrochemical synthesis of a triplet-spin state $(S$ $=1) \mathrm{Co}(\mathrm{III})$ thiolate compound and its redox interconversion to a $\mathrm{Co}$ (II) disulfide compound triggered by the removal of chloride ions. ${ }^{24}$ Herein, we report a low-spin $(S=0) \mathrm{Co}(\mathrm{III})$ thiolate compound, which was formed directly from a reaction of a cobalt(II) salt with ligand di-2-(bis(2-pyridylmethyl)amino)-ethyl disulfide $\left(\mathrm{L}^{1} \mathrm{SSL}^{1}\right)$. The redox interconversion of this $\mathrm{Co}(\mathrm{III})$ thiolate compound and the related $\mathrm{Co}(\mathrm{II})$ disulfide compound has been investigated. For comparison, the reaction of disulfide ligand $\mathrm{L}^{1} \mathrm{SSL}^{1}$ with iron(II) salts has been explored. This study not only provides a chemical perspective into the operation principle of electron transfer in metalloenzymes but also extends the research on thiolate/ disulfide interconversion to other metal centers.

\section{RESULTS}

Synthesis and Characterization of the Cobalt and Iron Compounds. Ligand di-2-(bis(2-pyridylmethyl)amino)ethyl disulfide $\left(\mathrm{L}^{1} \mathrm{SSL}^{1}\right)$ was synthesized using the reported procedure. $^{20}$ The coordination compounds were prepared following the procedure shown in Scheme 2. All the reactions were carried out under an oxygen-free atmosphere at room temperature, using standard Schlenk-line and glovebox techniques. Addition of 2 equiv of $\mathrm{CoCl}_{2} \cdot 6 \mathrm{H}_{2} \mathrm{O}$ to ligand $\mathrm{L}^{1} \mathrm{SSL}^{1}$ dissolved in acetonitrile led to the formation of a purple solution, from which the compound $\left[\mathrm{Co}_{2}{ }_{2}\left(\mathrm{~L}^{1} \mathrm{SSL}^{1}\right) \mathrm{Cl}_{4}\right]$ $\left(\mathbf{1}_{\mathrm{Co}}\right)$ was isolated in a yield of $64 \%$. Addition of 2 equiv of $\mathrm{FeCl}_{2} \cdot 4 \mathrm{H}_{2} \mathrm{O}$ to ligand $\mathrm{L}^{1} \mathrm{SSL}^{1}$ dissolved in methanol led to the formation of a greenish yellow solution, from which the compound $\left[\mathrm{Fe}^{\mathrm{II}}{ }_{2}\left(\mathrm{~L}^{1} \mathrm{SSL}^{1}\right) \mathrm{Cl}_{4}\right]\left(\mathbf{1}_{\mathrm{Fe}}\right)$ was isolated in a yield of $62 \%$. The addition of 2 equiv of $\left[\mathrm{Co}(\mathrm{MeCN})_{6}\right]\left(\mathrm{BF}_{4}\right)_{2}$ to ligand $\mathrm{L}^{1} \mathrm{SSL}^{1}$ dissolved in acetonitrile resulted in a brown solution from which a compound with the assumed formula $\left[\mathrm{Co}^{\mathrm{III}}\left(\mathrm{L}^{1} \mathrm{~S}\right)(\mathrm{MeCN})_{2}\right]\left(\mathrm{BF}_{4}\right)_{2}$ (2) was isolated as a brown oily material (in a yield of $65 \%$ ). Reaction of 2 equiv of $\mathrm{Co}(\mathrm{NCS})_{2}$ with 1 equiv of ligand $\mathrm{L}^{1} \mathrm{SSL}^{1}$ dissolved in acetonitrile provided a brown precipitate of the $\mathrm{Co}(\mathrm{III})$ compound $\left[\mathrm{Co}^{\mathrm{III}}\left(\mathrm{L}^{1} \mathrm{~S}\right)\right.$ $\left.(\mathrm{NCS})_{2}\right](3)$ in a yield of $70 \%$. In contrast, reaction of 2 equiv of $\left[\mathrm{Fe}(\mathrm{MeCN})_{6}\right]\left(\mathrm{BF}_{4}\right)_{2}$ with 1 equiv of ligand $\mathrm{L}^{1} \mathrm{SSL}^{1}$ dissolved in acetonitrile did not result in the anticipated $\mathrm{Fe}$ (III) thiolate compound but instead yielded a tetranuclear iron(II) fluoride compound. ${ }^{25}$ The cobalt and iron compounds were characterized by using ${ }^{1} \mathrm{H}$ NMR, UV-vis, Raman, and IR spectroscopy, electrospray ionization mass spectrometry (ESIMS), elemental analysis, and single crystal X-ray crystallography.

ESI-MS spectra of purple compound $\mathbf{1}_{\text {Co }}$ dissolved in acetonitrile show a dominant peak $(\mathrm{m} / \mathrm{z})$ at 740.8 corresponding to the fragment $\left[\mathrm{Co}_{2}{ }_{2}\left(\mathrm{~L}^{1} \mathrm{SSL}^{1}\right) \mathrm{Cl}_{3}\right]^{+}$(Figure S1). The ${ }^{1} \mathrm{H}$ NMR spectrum of the compound in dimethyl sulfoxide- $d_{6}$ shows broad resonances with shifts down to around $75 \mathrm{ppm}$ (Figure S2), indicative of a paramagnetic compound. The effective magnetic moment of compound $\mathbf{1}_{\mathrm{Co}}$ was estimated using Evans' method in dimethyl sulfoxide solution at $20{ }^{\circ} \mathrm{C}$, revealing a $\mu_{\text {eff }}$ of $6.53 \mu_{\mathrm{B}}{ }^{26,27}$ This value is in agreement with two (weakly interacting) high-spin $\mathrm{Co}$ (II) centers (a value of $6.93 \mu_{\mathrm{B}}$ is expected for two isolated $S=3 / 2$ cobalt(II) ions). ESI-MS spectra of compound $\mathbf{1}_{\mathrm{Fe}}$ dissolved in methanol present a peak $(\mathrm{m} / \mathrm{z})$ at 349.1 corresponding to the dicationic species $\left[\mathrm{Fe}_{2}{ }_{2}\left(\mathrm{~L}^{1} \mathrm{SSL}^{1}\right) \mathrm{Cl}_{2}\right]^{2+}$ (Figure S3). The effective magnetic moment of $\mathbf{1}_{\mathrm{Fe}}$ determined in methanol solution at

Scheme 2. Reactions of Ligand $\mathrm{L}^{1} \mathrm{SSL}^{1}$ with Different Cobalt(II) and Iron(II) Salts

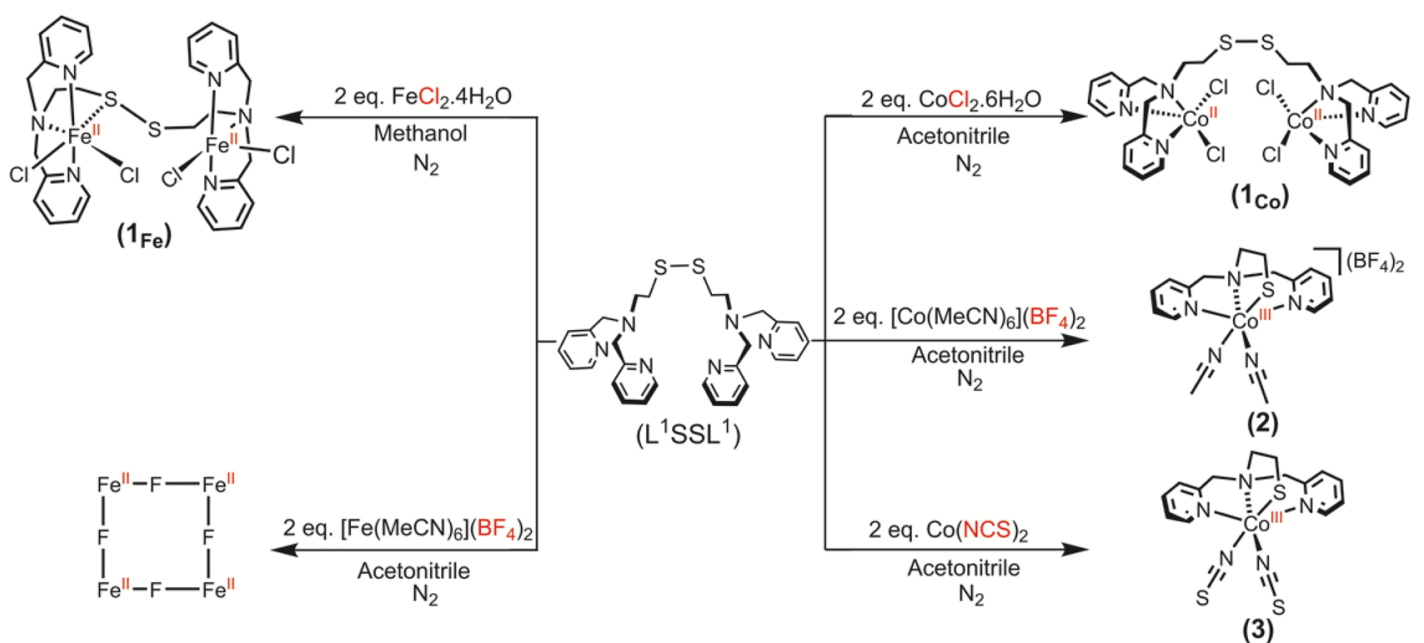




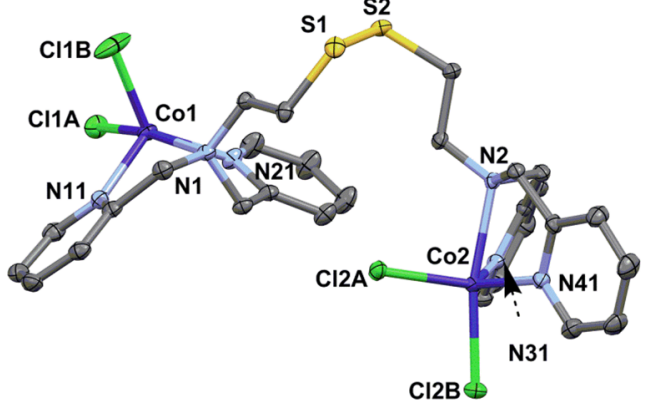

(a)

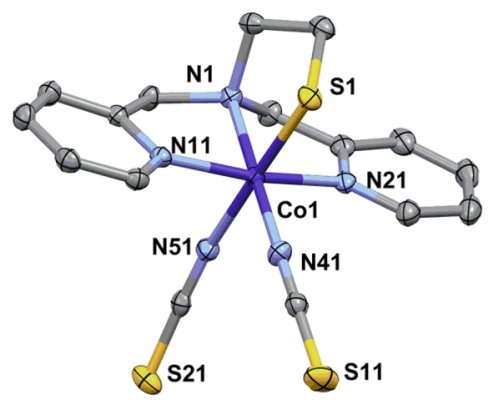

(b)

Figure 1. Displacement ellipsoid plots (50\% probability level) of compounds (a) $\left[\mathrm{Co}_{2}^{\mathrm{II}}\left(\mathrm{L}^{1} \mathrm{SSL}^{1}\right) \mathrm{Cl}_{4}\right]\left(\mathbf{1}_{\mathrm{Co}}\right)$ and (b) major component of $\left[\mathrm{Co}^{\mathrm{III}}\left(\mathrm{L}^{1} \mathrm{~S}\right)(\mathrm{NCS})_{2}\right](3)$ at $110(2) \mathrm{K}$. The lattice solvent molecule and hydrogen atoms are omitted for clarity. In the structure of 3 , partial oxidation of S1 was found (occupancy of the oxygen atom is 0.178(5)); a projection of the structure of the minor component is shown in Figure S16.

Table 1. Selected Bond Distances $(\AA)$ in the Structures of Compounds $1_{\mathrm{Co}}$ and 3 , as well as from the DFT-Optimized Structures of $\mathbf{1}_{\mathrm{Co}}, 3$, Cationic Part of 2 , and Theoretical Intermediates $\left[\mathrm{Co}^{\mathrm{III}}\left(\mathrm{L}^{1} \mathrm{~S}\right)(\mathrm{Cl})(\mathrm{NCS})\right](3 \mathrm{a})$ and $\left[\mathrm{Co}^{\mathrm{III}}\left(\mathrm{L}^{1} \mathrm{~S}\right) \mathrm{Cl}_{2}\right](4)^{a}$

\begin{tabular}{|c|c|c|c|c|c|c|c|}
\hline \multirow[b]{2}{*}{ bond } & \multicolumn{2}{|c|}{$\mathbf{1}_{\mathrm{Co}}$} & \multirow{2}{*}{$\begin{array}{c}2 \\
\text { DFT }\end{array}$} & \multicolumn{2}{|c|}{3} & \multirow{2}{*}{$\begin{array}{c}3 \mathbf{a} \\
\text { DFT }\end{array}$} & \multirow{2}{*}{$\begin{array}{c}4 \\
\text { DFT }\end{array}$} \\
\hline & XRD & DFT & & XRD & DFT & & \\
\hline Col-N1 & $2.311(2)$ & 2.392 & 1.942 & $1.9558(15)$ & 1.947 & 1.947 & 1.950 \\
\hline Co1-N11 & $2.064(2)$ & 2.061 & 1.932 & $1.9235(14)$ & 1.922 & 1.916 & 1.918 \\
\hline Co1-N21 & $2.084(2)$ & 2.057 & 1.932 & $1.9332(15)$ & 1.924 & 1.917 & 1.923 \\
\hline Co1-S1 & $5.9614(8)$ & 6.004 & 2.206 & $2.2355(5)$ & 2.211 & 2.208 & 2.202 \\
\hline Co1-X1 & $2.3240(7)$ & 2.330 & 1.857 & $1.9011(16)$ & 1.855 & 1.851 & 2.261 \\
\hline Co1-X2 & $2.2716(8)$ & 2.291 & 1.951 & $1.9934(15)$ & 1.934 & 2.356 & 2.360 \\
\hline
\end{tabular}

${ }^{a}$ See the Discussion section below. X1 = Cl1A, X2 = Cl1B for $\mathbf{1}_{\mathrm{Co}}$; X1 = N41, X2 = N51 for 2 and 3; X1 = N41, X2 = Cl1 for 3a; X1 = Cl1A, X2 = Cl1B for 4. All calculations were performed in the solvent.

Table 2. Selected Bond Angles (deg) in the Structures of $\mathbf{1}_{\mathrm{Co}}$ and 3

\begin{tabular}{|c|c|c|c|c|c|}
\hline \multicolumn{2}{|c|}{$\mathbf{1}_{\mathrm{Co}}$} & \multicolumn{4}{|c|}{3} \\
\hline Cl1A-Co1-Cl1B & $100.76(3)$ & S1-Co1-N41 & $88.93(5)$ & N51-Co1-N11 & $88.17(6)$ \\
\hline $\mathrm{Cl} 1 \mathrm{~A}-\mathrm{Co} 1-\mathrm{N} 1$ & $169.92(6)$ & S1-Co1-N51 & $178.43(5)$ & N51-Co1-N21 & $91.59(6)$ \\
\hline $\mathrm{Cl1A}-\mathrm{Co} 1-\mathrm{N} 11$ & $102.96(6)$ & $\mathrm{S} 1-\mathrm{Co} 1-\mathrm{N} 1$ & $90.38(4)$ & $\mathrm{N} 1-\mathrm{Co} 1-\mathrm{N} 11$ & $84.32(6)$ \\
\hline $\mathrm{Cl} 1 \mathrm{~A}-\mathrm{Co}-\mathrm{N} 21$ & $97.12(6)$ & S1-Co1-N11 & $92.10(4)$ & $\mathrm{N} 1-\mathrm{Co} 1-\mathrm{N} 21$ & $84.77(6)$ \\
\hline $\mathrm{Cl1B}-\mathrm{Co} 1-\mathrm{N} 1$ & $89.29(5)$ & $\mathrm{S} 1-\mathrm{Co} 1-\mathrm{N} 21$ & $88.44(4)$ & N11-Co1-N21 & $169.09(6)$ \\
\hline Cl1B-Co1-N11 & $101.81(7)$ & N41-Co1-N51 & $89.50(6)$ & & \\
\hline $\mathrm{Cl1B}-\mathrm{Co} 1-\mathrm{N} 21$ & $133.71(7)$ & $\mathrm{N} 41-\mathrm{Co} 1-\mathrm{N} 1$ & $179.31(7)$ & & \\
\hline N1-Co1-N11 & $75.42(8)$ & N41-Co1-N11 & $95.65(6)$ & & \\
\hline $\mathrm{N} 1-\mathrm{Co} 1-\mathrm{N} 21$ & $75.05(8)$ & $\mathrm{N} 41-\mathrm{Co} 1-\mathrm{N} 21$ & $95.26(7)$ & & \\
\hline N11-Co1-N21 & $115.20(9)$ & $\mathrm{N} 51-\mathrm{Co} 1-\mathrm{N} 1$ & $91.18(6)$ & & \\
\hline
\end{tabular}

$20{ }^{\circ} \mathrm{C}$ is in agreement with the presence of two high-spin $\mathrm{Fe}(\mathrm{II})$ centers in this compound ( $\mu_{\text {eff }}=7.67 \mu_{\mathrm{B}} ; 8.94 \mu_{\mathrm{B}}$ is expected for two isolated $S=2$ iron(II) centers). ESI-MS spectra of 2 dissolved in acetonitrile show a dominant peak $(m / z)$ at 199.8 for the dicationic species $\left[\mathrm{Co}^{\mathrm{III}}\left(\mathrm{L}^{1} \mathrm{~S}\right)\right.$ $\left.(\mathrm{MeCN})_{2}\right]^{2+}$ (Figure S4). The ${ }^{1} \mathrm{H}$ NMR spectrum of brown compound 2 in acetonitrile- $d_{3}$ shows resonances in the diamagnetic region, consistent with the $\mathrm{Co}$ (III) center in this compound being in a low-spin state (Figure S5). Similarly, the ${ }^{1} \mathrm{H}$ NMR spectrum of compound 3 in acetonitrile- $d_{3}$ shows resonances in the diamagnetic region (Figure S6). ESI-MS spectra of brown compound 3 dissolved in acetonitrile show a dominant peak $(\mathrm{m} / \mathrm{z})$ at 375.3 corresponding to the fragment $\left[\mathrm{Co}^{\mathrm{III}}\left(\mathrm{L}^{1} \mathrm{~S}\right)(\mathrm{NCS})\right]^{+}$(Figure $\mathrm{S} 8$ ).

Confocal Raman spectroscopy using a $476 \mathrm{~nm}$ laser was employed to study the disulfide bond in compounds $\mathbf{1}_{\mathrm{Co}}, \mathbf{1}_{\mathrm{Fe}}$, 2, and disulfide ligand $\mathrm{L}^{1} \mathrm{SSL}^{1}$. The obtained spectra are provided in Figures S9 and S10. The Raman spectrum of ligand $\mathrm{L}^{1} \mathrm{SSL}^{1}$ shows clear bands at 522 and $550 \mathrm{~cm}^{-1}$, which are attributed to the $S-S$ bond vibration. ${ }^{28}$ These bands are retained in the Raman spectra of $\mathbf{1}_{\mathrm{Co}}$ and $\mathbf{1}_{\mathrm{Fe}}$ and as expected are not present in the spectrum of 2 .

Attempts were undertaken to investigate the electrochemical properties of the cobalt compounds $\mathbf{1}_{\mathrm{Co}}, \mathbf{2}$, and $\mathbf{3}$ using cyclic voltammetry in acetonitrile solutions with $0.1 \mathrm{M}$ tetrabutylammonium hexafluoridophosphate as the supporting electrolyte (Figures S11-S14). Unfortunately, the compounds show multiple, poorly resolved redox waves, making it difficult to assign the various processes occurring in the solutions.

Description of the Crystal Structures. Single crystals of $\mathbf{1}_{\mathrm{Co}}$ and $\mathbf{3}$ suitable for X-ray structure determination were obtained by vapor diffusion of diethyl ether and diisopropyl ether into acetonitrile solutions containing the compounds. Single crystals of $\mathbf{1}_{\mathrm{Fe}}$ were grown by vapor diffusion of diethyl 
ether into a methanolic solution of the compound. Unfortunately, single crystals of $\mathbf{2}$ could not be obtained, but after 8 weeks from an acetonitrile solution of compound $\mathbf{2}$ kept in air, crystals were obtained of the cobalt(III) sulfinate compound $\left[\mathrm{Co}^{\mathrm{III}}\left(\mathrm{L}^{1} \mathrm{SO}_{2}\right)(\mathrm{MeCN})_{2}\right]\left(\mathrm{BF}_{4}\right)_{2}\left(2_{\mathrm{Ox}}\right)$. The crystal structure of $\mathbf{2}_{\mathrm{Ox}}$ has been determined, and a projection of the structure is provided in Figure S15. Crystallographic and refinement data of the structures are provided in Table S1. A projection of the dinuclear structure of $\mathbf{1}_{\mathrm{Co}}$ is shown in Figure 1a; relevant bond distances and angles are given in Tables 1 and 2. Compound $\mathbf{1}_{\mathrm{Co}}$ crystallizes in the centrosymmetric space group $P \overline{1}$, with one dinuclear complex and one molecule of diethyl ether cocrystallized in the asymmetric unit. The two $\mathrm{Co}$ (II) ions are bound to three nitrogen atoms of ligand and two chloride ions in distorted trigonal-bipyramidal geometries with the tertiary amine nitrogen and one of the chloride ions in the apical positions. The calculated $\tau$ values of the 5coordinated geometries are 0.60 and 0.72 for $\mathrm{Co} 1$ and $\mathrm{Co} 2$, respectively. The $\tau$ value is determined from the two largest bond angles and is between 0 and 1 , where 0 presents a perfect square-planar geometry and 1 corresponds to an ideal trigonalbipyramidal geometry. ${ }^{29}$ The cobalt-to-nitrogen bond lengths range from $2.064(2)$ to $2.311(2) \AA$. The sulfur atoms of the disulfide bond are noncoordinating; the $\mathrm{Co}-\mathrm{S}$ distances are 5.9614(8) and 5.9371(7) $\AA$. The distance between the two cobalt ions within the dinuclear structure is $8.1617(6) \AA$. Hydrogen-bond or stacking interactions are not present in this structure.

A projection of the dinuclear structure of $\mathbf{1}_{\mathrm{Fe}}$ is shown in Figure 2; relevant bond distances and angles are presented in

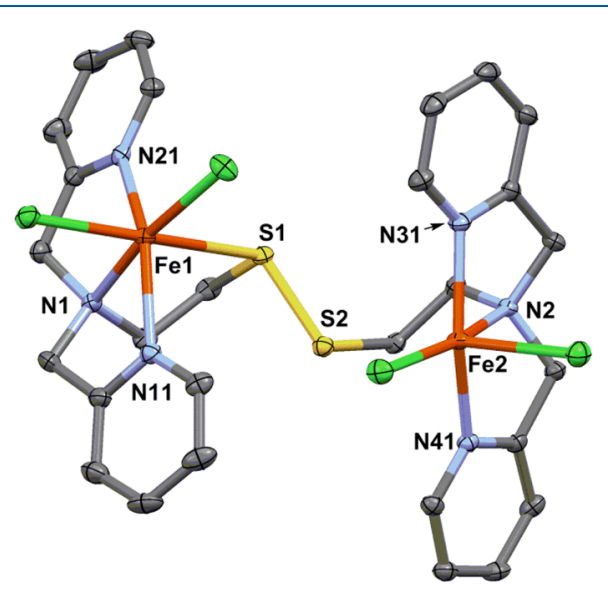

Figure 2. Displacement ellipsoid plots (50\% probability level) of the compound $\left[\mathrm{Fe}_{2}{ }_{2}\left(\mathrm{~L}^{1} \mathrm{SSL}^{1}\right) \mathrm{Cl}_{4}\right]\left(\mathbf{1}_{\mathrm{Fe}}\right)$ at $110(2) \mathrm{K}$. The lattice solvent molecule and hydrogen atoms are omitted for clarity.

Table 3. Compound $\mathbf{1}_{\mathrm{Fe}}$ crystallizes in the monoclinic space group $C c$, with two lattice methanol solvent molecules in the asymmetric unit. The two $\mathrm{Fe}(\mathrm{II})$ centers in this dinuclear compound are in different geometries. Fel is in an octahedral geometry coordinated by two chloride ions, one thioether sulfur, and three nitrogen donor atoms of the ligand. The three nitrogen donors are bound in a meridional fashion, and the two chloride ions are in mutual cis positions, one of them trans to the thioether sulfur and the other trans to the tertiary amine. $\mathrm{Fe} 2$ is bound to two chloride ions and three nitrogen donors of the ligand in a pseudo-square-pyramidal geometry with a $\tau$ value of $0.25 ;{ }^{29}$ also, in this case the three nitrogen donors are bound in a meridional fashion in the equatorial plane of the square pyramid. The Fe1-S1 bond length is 2.6925(8) $\AA$, which is much shorter than the Fe2-S2 distance of 3.231(1) $\AA$ but longer than the $\mathrm{Fe}-\mathrm{S}$ bond distances in some reported thioether-Fe(II) compounds (ranging from 2.200 to 2.285 $\AA$ ).$^{30-32}$ The $\mathrm{Fe}-\mathrm{N}$ bond distances range from $2.135(2)$ to 2.270(3) $\AA$ for both $\mathrm{Fe}^{\mathrm{II}}$ ions, in agreement with a high-spin state $(S=2)$ of both iron(II) centers. One of the two lattice methanol molecules is hydrogen bound to one of the coordinated chloride ions. The crystal packing of this structure shows no stacking interactions.

A projection of the mononuclear structure of 3 is shown in Figure $1 \mathrm{~b}$; relevant bond distances and angles are presented in Tables 1 and 2. Compound 3 crystallizes in the orthorhombic space group $\mathrm{Pbca}$. The $\mathrm{Co}(\mathrm{III})$ ion is coordinated by three nitrogen donor atoms, one thiolate sulfur donor of the tetradentate ligand, and two nitrogen atoms of the thiocyanate anions in an octahedral geometry. The three nitrogen atoms of the tetradentate ligand are bound in a meridional fashion. The Co-S bond length is 2.2355(5) $\AA$; the bond distances between the cobalt center and the five nitrogen donor atoms range from $1.9011(16)$ to $1.9934(15) \AA$. The thiocyanate donor atom N51 is at a significantly larger distance than N41, indicative of a larger trans influence of the thiolate sulfur donor. When finalizing the refinement, a residual electron density peak of $2.47 \mathrm{e}^{-} \AA^{-3}$ was found at ca. $1.46 \AA$ from S1. This peak is thought to arise from an oxygen atom, and its presence may result from the partial oxidation of S1 occurring during the crystallization process. Single crystals were obtained only after 3 weeks, during which time dioxygen must have diffused into the flask. Such a mono-oxygenated product likely is an intermediate in the oxidation of $\mathrm{Co}$ (III)-thiolate compound 2 to dioxygenated product $\mathbf{2}_{\mathrm{Ox}}$, containing a sulfinate ligand (Figure S15). A projection of the compound $\left[\mathrm{Co}^{\mathrm{III}}\left(\mathrm{L}^{1} \mathrm{SO}\right)\right.$ (NCS) $)_{2}$ (which is present with an occupancy factor of $0.178(5)$ ) is given in Figure S16. Hydrogen-bond or stacking interactions are not present in this compound.

UV-vis Spectroscopy and Reactivity. UV-vis spectra of purple $\mathbf{1}_{\mathrm{Co}}$ dissolved in acetonitrile show four absorption bands (Figure 3a, black line). The absorption band at $261 \mathrm{~nm}$ $\left(\varepsilon=4.6 \times 10^{3} \mathrm{M}^{-1} \mathrm{~cm}^{-1}\right)$ is assigned to the $\pi \rightarrow \pi^{*}$ transition of the pyridyl groups, whereas the three low-intensity bands at $524\left(\varepsilon=0.1 \times 10^{3} \mathrm{M}^{-1} \mathrm{~cm}^{-1}\right), 570\left(\varepsilon=0.1 \times 10^{3} \mathrm{M}^{-1} \mathrm{~cm}^{-1}\right)$, and $640\left(\varepsilon=0.1 \times 10^{3} \mathrm{M}^{-1} \mathrm{~cm}^{-1}\right)$ nm likely correspond to $\mathrm{d}-$ $\mathrm{d}$ transitions that are partially spin-allowed by $\mathrm{d}-\mathrm{p}$ orbital mixing, combined with a $\mathrm{Cl} \rightarrow \mathrm{Co}^{\mathrm{II}}$ charge-transfer transition (LMCT). ${ }^{33}$ Absorption bands for the solid sample appear at 216, 253, 508, 595, and $797 \mathrm{~nm}$ (Figure S17). UV-vis spectra of brown compound 2 dissolved in acetonitrile reveal three absorption bands (Figure 3a, blue line). The band at $262 \mathrm{~nm}$ $\left(\varepsilon=8.1 \times 10^{3} \mathrm{M}^{-1} \mathrm{~cm}^{-1}\right)$ is ascribed to $\pi \rightarrow \pi^{*}$ transition of the pyridyl groups, whereas the two absorption bands at $287 \mathrm{~nm}(\varepsilon$ $\left.=6.9 \times 10^{3} \mathrm{M}^{-1} \mathrm{~cm}^{-1}\right)$ and $441 \mathrm{~nm}\left(\varepsilon=0.4 \times 10^{3} \mathrm{M}^{-1} \mathrm{~cm}^{-1}\right)$ are tentatively ascribed to ligand-to-metal charge-transfer transitions (LMCT). UV-vis spectra of compound 3 dissolved in acetonitrile present four absorption bands (Figure S18). The absorption bands at 238 and $279 \mathrm{~nm}$ are assigned to the $\pi \rightarrow \pi^{*}$ transitions of the pyridyl groups, whereas the two absorption bands at 325 and $515 \mathrm{~nm}$ likely correspond to LMCT transitions. ${ }^{33,34}$ The UV-vis spectrum of 3 in the solid state presents four absorption bands at 268, 336, 514, and $667 \mathrm{~nm}$ (Figure S19). UV-vis spectra of $\mathbf{1}_{\mathrm{Fe}}$ dissolved in methanol show one strong absorption band at $256 \mathrm{~nm}\left(\varepsilon=8.6 \times 10^{3}\right.$ $\mathrm{M}^{-1} \mathrm{~cm}^{-1}$ ) corresponding to the $\pi \rightarrow \pi^{*}$ transition of pyridyl 
Table 3. Selected Bond Distances $(\AA)$ and Angles $(\mathrm{deg})$ in the Crystal Structure of $\left[\mathrm{Fe}^{\mathrm{II}}{ }_{2}\left(\mathrm{~L}^{1} \mathrm{SSL}^{1}\right) \mathrm{Cl}_{4}\right]\left(1_{\mathrm{Fe}}\right)$ as well as from DFT-Optimized Structures of the Compound with Different Spin States $(S=2$ and 0 for Both Iron Centers)

\begin{tabular}{|c|c|c|c|c|c|c|c|}
\hline distances & XRD & DFT $(S=2,2)$ & $\operatorname{DFT}(S=0,0)$ & angles & $\mathrm{XRD}$ & angles & XRD \\
\hline $\mathrm{Fe} 1-\mathrm{N} 1$ & $2.270(2)$ & 2.355 & 1.970 & Cl1A-Fe1-Cl1B & $100.40(3)$ & $\mathrm{Cl} 2 \mathrm{~A}-\mathrm{Fe} 2-\mathrm{Cl} 2 \mathrm{~B}$ & $101.45(3)$ \\
\hline $\mathrm{Fe} 1-\mathrm{N} 11$ & $2.198(2)$ & 2.129 & 1.942 & $\mathrm{Cl1A}-\mathrm{Fe} 1-\mathrm{N} 1$ & $93.12(6)$ & $\mathrm{Cl} 2 \mathrm{~A}-\mathrm{Fe} 2-\mathrm{N} 2$ & $165.76(6)$ \\
\hline $\mathrm{Fe} 1-\mathrm{N} 21$ & $2.187(2)$ & 2.131 & 1.969 & Cl1A-Fe1-N11 & $93.08(6)$ & $\mathrm{Cl} 2 \mathrm{~A}-\mathrm{Fe} 2-\mathrm{N} 31$ & $103.69(7)$ \\
\hline $\mathrm{Fe} 1-\mathrm{S} 1$ & $2.6925(8)$ & 3.506 & 2.105 & $\mathrm{Cl1A}-\mathrm{Fe} 1-\mathrm{N} 21$ & $93.56(6)$ & $\mathrm{Cl} 2 \mathrm{~A}-\mathrm{Fe} 2-\mathrm{N} 41$ & $102.55(6)$ \\
\hline $\mathrm{Fe} 1-\mathrm{Cl} 1 \mathrm{~A}$ & $2.4228(8)$ & 2.415 & 2.413 & $\mathrm{Cl1B}-\mathrm{Fe} 1-\mathrm{N} 1$ & $166.05(6)$ & $\mathrm{Cl} 2 \mathrm{~B}-\mathrm{Fe} 2-\mathrm{N} 2$ & $92.79(6)$ \\
\hline $\mathrm{Fe} 1-\mathrm{Cl1B}$ & $2.3419(7)$ & 2.297 & 2.323 & $\mathrm{Cl1B}-\mathrm{Fe} 1-\mathrm{N} 11$ & $108.65(6)$ & $\mathrm{Cl} 2 \mathrm{~B}-\mathrm{Fe} 2-\mathrm{N} 31$ & $94.52(6)$ \\
\hline$S 1-S 2$ & $2.0576(9)$ & 2.030 & 2.979 & $\mathrm{Cl} 1 \mathrm{~B}-\mathrm{Fe} 1-\mathrm{N} 21$ & $99.94(6)$ & $\mathrm{Cl} 2 \mathrm{~B}-\mathrm{Fe} 2-\mathrm{N} 41$ & $93.26(6)$ \\
\hline $\mathrm{Fe} 2-\mathrm{N} 2$ & $2.255(2)$ & 2.355 & 1.969 & $\mathrm{~N} 1-\mathrm{Fe} 1-\mathrm{N} 11$ & $73.77(8)$ & $\mathrm{N} 2-\mathrm{Fe} 2-\mathrm{N} 31$ & $75.26(8)$ \\
\hline $\mathrm{Fe} 2-\mathrm{N} 31$ & $2.141(2)$ & 2.129 & 1.943 & $\mathrm{~N} 1-\mathrm{Fe} 1-\mathrm{N} 21$ & $75.57(8)$ & $\mathrm{N} 2-\mathrm{Fe} 2-\mathrm{N} 41$ & $75.98(8)$ \\
\hline $\mathrm{Fe} 2-\mathrm{N} 41$ & $2.135(2)$ & 2.132 & 1.968 & $\mathrm{~N} 11-\mathrm{Fe} 1-\mathrm{N} 21$ & $148.92(8)$ & $\mathrm{N} 31-\mathrm{Fe} 2-\mathrm{N} 41$ & $150.51(9)$ \\
\hline $\mathrm{Fe} 2-\mathrm{S} 2$ & $3.231(1)$ & 3.509 & 2.106 & $\mathrm{Cl1A}-\mathrm{Fe} 1-\mathrm{S} 1$ & $170.91(3)$ & & \\
\hline $\mathrm{Fe} 2-\mathrm{Cl} 2 \mathrm{~A}$ & $2.3035(8)$ & 2.293 & 2.324 & $\mathrm{Cl1B}-\mathrm{Fe} 1-\mathrm{S} 1$ & $86.37(3)$ & & \\
\hline $\mathrm{Fe} 2-\mathrm{Cl} 2 \mathrm{~B}$ & $2.4241(8)$ & 2.416 & 2.414 & $\mathrm{~S} 1-\mathrm{Fe} 1-\mathrm{N} 1$ & $79.83(6)$ & & \\
\hline \multirow[t]{2}{*}{$\mathrm{Fe} 1-\mathrm{Fe} 2$} & $6.0567(6)$ & 7.150 & 6.433 & $\mathrm{~S} 1-\mathrm{Fe} 1-\mathrm{N} 11$ & $90.45(6)$ & & \\
\hline & & & & $\mathrm{S} 1-\mathrm{Fe} 1-\mathrm{N} 21$ & $79.20(6)$ & & \\
\hline
\end{tabular}
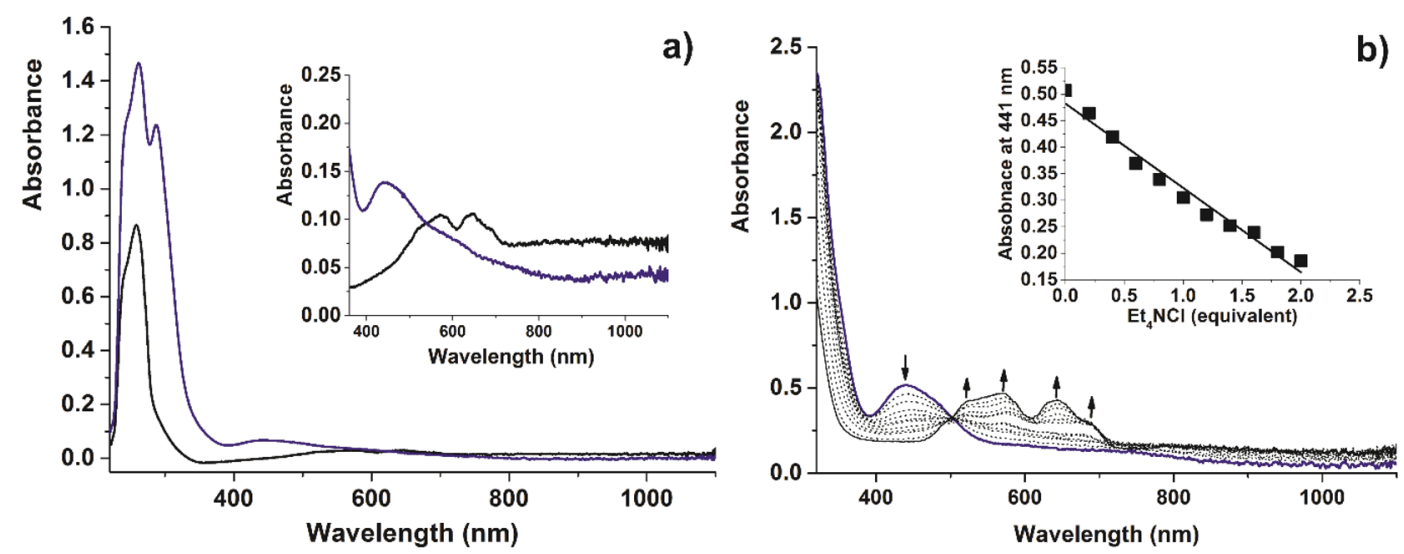

Figure 3. (a) UV-vis spectra of $\mathbf{1}_{\mathrm{Co}}$ (black) and $\mathbf{2}$ (blue). UV-vis spectra were recorded using solutions $1 \mathrm{mM}$ in [Co] with a transmission dip probe path length of $1.8 \mathrm{~mm}$. The inset shows the UV-vis spectra of compounds recorded of solutions $2 \mathrm{mM}$ in [Co]. (b) UV-vis spectra recorded upon addition of $\mathrm{Et}_{4} \mathrm{NCl}$ to a solution of the compound $\left[\mathrm{Co}^{\mathrm{III}}\left(\mathrm{L}^{1} \mathrm{~S}\right)(\mathrm{MeCN})_{2}\right]\left(\mathrm{BF}_{4}\right)_{2}(2)$ in acetonitrile. The spectra were recorded in at a concentration of $10 \mathrm{mM}$ [Co] with a transmission dip probe path length of $2.3 \mathrm{~mm}$. The inset shows the change of absorbance at $441 \mathrm{~nm}$ with addition of $\mathrm{Et}_{4} \mathrm{NCl}$.

groups. In addition, two weaker bands are observed at $313 \mathrm{~nm}$ $\left(\varepsilon=1.0 \times 10^{3} \mathrm{M}^{-1} \mathrm{~cm}^{-1}\right)$ and $390 \mathrm{~nm}\left(\varepsilon=1.8 \times 10^{3} \mathrm{M}^{-1}\right.$ $\mathrm{cm}^{-1}$ ) tentatively ascribed to metal-to-ligand charge transfer (MLCT) transitions (Figure S20). The UV-vis spectrum of $\mathbf{1}_{\mathrm{Fe}}$ in the solid state presents two bands: one at $256 \mathrm{~nm}$ and another broad band at around $353 \mathrm{~nm}$ (Figure S21).

To investigate the potential redox interconversion between the cobalt(II) disulfide compound and the cobalt(III) thiolate compound (Scheme 3), tetraethylammonium chloride was titrated into the acetonitrile solution containing $\mathrm{Co}$ (III) compound 2 while the reaction was monitored using UV-

Scheme 3. Redox Interconversion Reaction of Co(II) Compound $1_{\mathrm{Co}}$ and $\mathrm{Co}$ (III) Compound 2 with the Addition or Removal of Chloride Anions

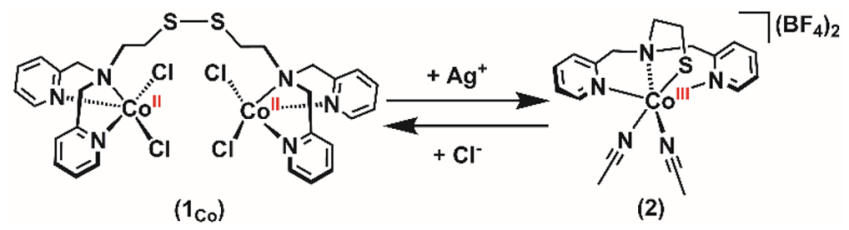

vis spectroscopy. The UV-vis spectra recorded during the addition of the chloride salt are shown in Figure $3 \mathrm{~b}$. With the addition of chloride ions into an acetonitrile solution of $\mathbf{2}$ the intensity of the absorption band at $441 \mathrm{~nm}$ gradually decreases until this band completely disappears after the addition of 2 equiv of chloride ion per cobalt center, while three new absorption bands appear at 524, 570, and $640 \mathrm{~nm}$. The final spectrum equals the absorption spectrum of $\mathrm{Co}(\mathrm{II})$ compound $\mathbf{1}_{\mathrm{Co}}$. Conversely, removal of chloride anions from $\mathrm{Co}(\mathrm{II})$ disulfide compound $\mathbf{1}_{\mathrm{Co}}$ by titration with $\mathrm{AgBF}_{4}$ leads to the regeneration of the $\mathrm{Co}^{\mathrm{III}}$-thiolate compound, as indicated by UV-vis spectroscopy (Figure S22).

The reaction of $\mathbf{1}_{\mathrm{Fe}}$ with $\mathrm{AgBF}_{4}$ in methanol solution was investigated as well, monitored by UV-vis spectroscopy under anaerobic conditions; the results are shown in Figure S23. With the addition of $\mathrm{AgBF}_{4}$ the absorption at $313 \mathrm{~nm}$ decreases and fully disappears after addition of 4 equiv of $\mathrm{AgBF}_{4}$, while the absorption band at $390 \mathrm{~nm}$ shifts to $368 \mathrm{~nm}$. ESI-MS spectra of the final reaction mixture show the presence of a large number of species, including a peak at $\mathrm{m} / \mathrm{z} 734.8$ for $\left[\mathrm{Fe}_{2}\left(\mathrm{~L}^{1} \mathrm{SSL}^{1}\right) \mathrm{Cl}_{3}\right]^{+}$, indicating that the reaction does not simply yield the anticipated $\mathrm{Fe}$ (III) thiolate compound. As described above, the direct reaction of $\mathrm{L}^{1} \mathrm{SSL}^{1}$ with $[\mathrm{Fe}-$ 
$\left.(\mathrm{MeCN})_{6}\right]\left(\mathrm{BF}_{4}\right)_{2}$ yielded a tetranuclear $\mathrm{Fe}(\mathrm{II})$ compound of the disulfide ligand with bridging fluoride ions. ${ }^{25}$

Computational Characterization. To explore the electronic structures of $\mathbf{1}_{\mathrm{Co}}, \mathbf{1}_{\mathrm{Fe}}, \mathbf{2}$, and $\mathbf{3}$ geometry optimizations were performed for all the compounds starting from the coordinates of the crystal structures. Quartet-spin $(S=3 / 2)$ and doublet-spin states $(S=1 / 2)$ of the $\mathrm{Co}(\mathrm{II})$ centers were considered for $\mathbf{1}_{\mathrm{Co}}$. High-spin $(S=2)$ and low-spin $(S=0)$ states of iron(II) centers were taken into account for $\mathbf{1}_{\mathrm{Fe}}$ and for the $\mathrm{Co}$ (III) center in the cationic parts of 2 and 3 . The obtained results are presented in Tables 1, 3, and S3-S6 and Figures S24-S27. Comparison of the experimental and computed structures shows that the geometry of the cobalt centers in $\mathbf{1}_{\text {Co }}$ with quartet-spin states (two $S=3 / 2$ ions) is more consistent with the crystallographic data. Furthermore, $\mathbf{1}_{\text {Co }}$ with quartet-spin states also has the lowest Gibbs free energy in the solvent, namely, $13 \mathrm{kcal} / \mathrm{mol}$ lower than for doublet-spin states (two $S=1 / 2$ ions). The optimized (solvation) structure for $\mathbf{1}_{\mathrm{Fe}}$ has the lowest Gibbs free energy with high-spin states $\left(\mathbf{1}_{\mathrm{Fe}(2,2, \mathrm{sol})}\right.$, two $S=2 \mathrm{Fe}^{\mathrm{II}}$ centers $)$, which is 31 and $10 \mathrm{kcal} / \mathrm{mol}$ lower than for the compound with two low-spin iron(II) centers $\left(\mathbf{1}_{\mathrm{Fe}(0,0, \mathrm{sol})}, S=0\right)$ and the compound

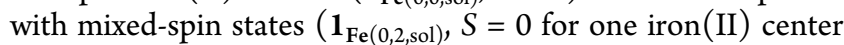
and $S=2$ for the other iron(II) center). The optimized geometry of $\mathbf{1}_{\mathrm{Fe}}$ with two high-spin iron(II) centers is roughly similar to the crystallographic data; however, both $\mathrm{Fe}$ (II) ions are in a five-coordinate configuration, with $\mathrm{Fe}-\mathrm{S}$ bond distances of 3.509 and $3.506 \AA$. For optimized compound $\mathbf{1}_{\mathrm{Fe}(0,0, \text { sol })}$ in the low-spin state ( $S=0$ for both $\mathrm{Fe}^{\mathrm{II}}$ ions), the $S-$ $S$ bond length is $2.979 \AA$, which is much longer than in the crystal structure of $\mathbf{1}_{\mathrm{Fe}}$, whereas the $\mathrm{Fe}-\mathrm{S}$ distances are much shorter than those in the crystal structure. Therefore, as the computations did not reproduce the $\mathrm{Fe}-\mathrm{S}$ distances, the geometry was optimized while keeping the distance between $\mathrm{Fe} 2$ and $\mathrm{S} 2$ fixed. The structure in the high-spin state $\left(\mathbf{1}_{\mathrm{Fe}(2,2, \text { sol,fixation }),} S=2\right.$ for both $\mathrm{Fe}^{\mathrm{II}}$ centers) still has the lowest Gibbs free energy and the acquired structure is consistent with the crystallographic data. Furthermore, the Gibbs free energy of $\mathbf{1}_{\mathrm{Fe}(2,2, \text { sol,fixation })}$ is nearly the same as that of

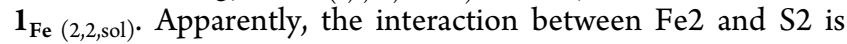
weak, and does not significantly affect the stability of the compound.

Both Co(III) compounds 2 and 3 have the lowest Gibbs free energy in the solvent with a low-spin $\mathrm{Co}$ (III) center, namely, 25 and $23 \mathrm{kcal} / \mathrm{mol}$ lower than those with a high-spin Co(III) center. The selected bond lengths in the optimized structures of compounds $\mathbf{2}$ and $\mathbf{3}$ with the lowest energy are provided in Table 1 . The Co-S bond lengths in the optimized structures of 2 and 3 are 2.206 and $2.211 \AA$, respectively, comparable to the Co-S bond length $(2.2355(5) \AA)$ found in the crystal structure of 3 . The calculations conducted in the gas phase show similar results with those in the solvent.

The addition of chloride anions to a solution containing cobalt(III)-thiolate compound 2 results in formation of cobalt(II)-disulfide compound $\mathbf{1}_{\mathrm{Co}}$. To investigate this process computationally, the acetonitrile molecules in $\mathbf{2}$ and the thiocyanate anions in $\mathbf{3}$ were displaced by chloride ions one by one. The geometries of the theoretical intermediates $\left[\mathrm{Co}^{\mathrm{III}}\left(\mathrm{L}^{1} \mathrm{~S}\right)(\mathrm{Cl})(\mathrm{MeCN})\right]^{+}(\mathbf{2 a}), \quad\left[\mathrm{Co}^{\mathrm{III}}\left(\mathrm{L}^{1} \mathrm{~S}\right)(\mathrm{Cl})(\mathrm{NCS})\right]$ (3a), and $\left[\mathrm{Co}^{\mathrm{III}}\left(\mathrm{L}^{1} \mathrm{~S}\right) \mathrm{Cl}_{2}\right]$ (4) were optimized and their highest occupied molecular orbitals (HOMOs) were analyzed and compared with those of $\mathbf{2}$ and $\mathbf{3}$ (Scheme 4). The Gibbs free energies of the two isomeric intermediates (with the
Scheme 4. Drawing of Compounds 2 and 3 and Theoretical Intermediates $2 \mathrm{a}, 3 \mathrm{a}$, and 4

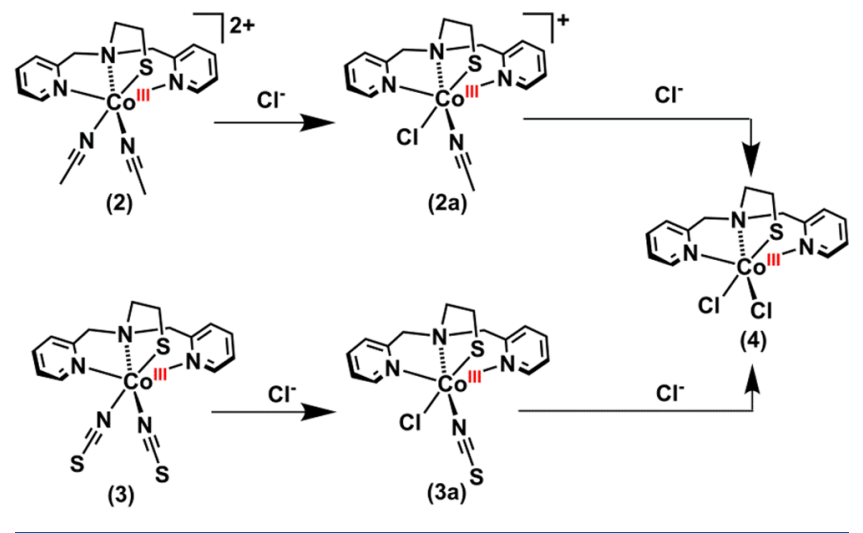

chloride ion placed in the position trans to the amine nitrogen donor) are slightly higher than those of intermediates $\mathbf{2 a}$ and $3 a$ ( 1 and $2 \mathrm{kcal} / \mathrm{mol}$, respectively). This small difference may be caused by the trans influence of the thiolate donor, but this was not investigated in detail. Interestingly, the HOMOs of compounds 3, 3a, and 4 consist mainly of p orbitals on sulfur and $\mathrm{d}$ orbitals on cobalt with the same total percentage ( $89 \%$ for all of the compounds). It was found that the HOMO gradually consists more of the $\mathrm{d}$ orbital on cobalt and less of the $\mathrm{p}$ orbital of sulfur, as the number of chloride anions increases and the number of coordinated thiocyanate anions decreases. Similarly, displacement of the acetonitrile molecules in 2 by chloride anions effect the same change on HOMOs (Figure S28).

It has been shown that depending on the experimental conditions dinuclear $\mathrm{Cu}(\mathrm{II})$ thiolate compounds $\left[\mathrm{Cu}^{\mathrm{II}}{ }_{2^{-}}\right.$ $\left.\left(\mathrm{L}^{1} \mathrm{~S}\right)_{2}\right]^{2+}$ with bridging thiolate donor atoms may be generated when $\mathrm{L}^{1} \mathrm{SSL}^{1}$ or similar disulfide ligands react with $\mathrm{Cu}(\mathrm{I})$ salts. $^{14,18-20,35}$ However, mononuclear rather than dinuclear $\mathrm{Co}$ (III) thiolate compounds are formed in our study. In order to understand this difference in reactivity, both the hypothetical dinuclear compounds $\left[\mathrm{Co}_{2}^{\mathrm{III}}\left(\mathrm{L}^{1} \mathrm{~S}\right)_{2}\right]^{4+}(5)$ and $\left[\mathrm{Co}_{2}{ }_{2}\left(\mathrm{~L}^{1} \mathrm{~S}\right)_{2}(\mathrm{MeCN})_{2}\right]^{4+}(6)$ with different spin states $(S=$ 0 , 1 , or 2 for both $\mathrm{Co}$ (III) ions) were investigated computationally. As a comparison, the hypothetical mononuclear copper compound $\left[\mathrm{Cu}^{\mathrm{II}}\left(\mathrm{L}^{1} \mathrm{~S}\right)(\mathrm{MeCN})\right]^{+}(7)$ and the actual dinuclear copper compound $\left[\mathrm{Cu}_{2}{ }_{2}\left(\mathrm{~L}^{1} \mathrm{~S}\right)_{2}\right]^{2+}(8)$ were optimized as well. The octahedral mononuclear copper(II) compound $\left[\mathrm{Cu}^{\mathrm{II}}\left(\mathrm{L}^{1} \mathrm{~S}\right)(\mathrm{MeCN})_{2}\right]^{+}$and the dinuclear copper(II) compound $\left[\mathrm{Cu}_{2}{ }_{2}\left(\mathrm{~L}^{1} \mathrm{~S}\right)_{2}(\mathrm{MeCN})_{2}\right]^{2+}$ have also been computed but are not discussed here as acetonitrile moved away from the $\mathrm{Cu}(\mathrm{II})$ center during the geometry optimization. The obtained results show that $\mathbf{5}$ has the lowest Gibbs free energy in the solvent with two low-spin cobalt(III) centers (two $S=0$ ions); two high-spin states (two $S=2$ ions) or two triplet-spin states (two $S=1$ ions) result in energies that are 40 and $3 \mathrm{kcal} / \mathrm{mol}$ higher. The energies of the antiferromagnetically coupled $(S=0)$ species were considered for the dinuclear copper(II) (two $S=1 / 2$ ions) and cobalt(III) (two $S=2$ ions in 5 or 6 , as well as two $S=1$ ions in 5 ) compounds (see the "Computational Characterization" section). Antiferromagnetic coupling $(S=0)$ is not beneficial to stabilize 5, for $S=2$ or 1 states result in Gibbs free energies being 29 and $24 \mathrm{kcal} / \mathrm{mol}$ higher than that of the uncoupled systems. The distance between two cobalt(III) ions in optimized geometries of $\mathbf{5}$ with two high-spin, two triplet- 
spin, and two low-spin states are $3.665,3.276$, and $3.097 \AA$, respectively (Figure S29). Similarly, 6 with two $S=0 \mathrm{Co}^{\mathrm{III}}$ centers has the lowest Gibbs free energy in solvent. Optimization of 6 with two high-spin $\mathrm{Co}^{\mathrm{III}}$ centers results in dissociation of the dinuclear structure (see Figure S30). Our computational study reveals that dimerization of mononuclear compound $\mathbf{2}$ to dinuclear compound $\mathbf{5}$ results in a slight decrease of the Gibbs free energy by $6 \mathrm{kcal} / \mathrm{mol}$; however, formation of 6 leads to an increase of the Gibbs free energy by $19 \mathrm{kcal} / \mathrm{mol}$ (Figure 4). The formation of dinuclear copper compound 8 from mononuclear compound 7 leads to stabilization, lowering the Gibbs free energy by $33 \mathrm{kcal} / \mathrm{mol}$ (Figure 4, Tables S6 and S7).

Gibbs free energy $(\mathrm{kcal} / \mathrm{mol})$



Figure 4. Optimized structures (at the ZORA-OPBE/TZ2P level of theory) of the compounds $\mathbf{2}$ and 5-8, and the change in Gibbs free energy (in $\mathrm{kcal} / \mathrm{mol}$ ) upon formation of the dinuclear metal compounds in acetonitrile. The acetonitrile molecules liberated in the reactions were taken into account but are omitted from the drawings for clarity.

\section{DISCUSSION}

The redox interconversion between metal thiolate and disulfide compounds has received considerable attention in the past decade. In this manuscript, we report the synthesis of four new cobalt and iron compounds $\left[\mathrm{Co}_{2}^{\mathrm{II}}\left(\mathrm{L}^{1} \mathrm{SSL}^{1}\right) \mathrm{Cl}_{4}\right] \quad\left(\mathbf{1}_{\mathrm{Co}}\right)$, $\left[\mathrm{Fe}_{2}^{\mathrm{II}}\left(\mathrm{L}^{1} \mathrm{SSL}^{1}\right) \mathrm{Cl}_{4}\right]\left(\mathbf{1}_{\mathrm{Fe}}\right),\left[\mathrm{Co}^{\mathrm{III}}\left(\mathrm{L}^{1} \mathrm{~S}\right)(\mathrm{MeCN})_{2}\right]\left(\mathrm{BF}_{4}\right)_{2}(\mathbf{2})$, and $\left[\mathrm{Co}^{\mathrm{III}}\left(\mathrm{L}^{1} \mathrm{~S}\right)(\mathrm{NCS})_{2}\right]$ (3) from reactions of the disulfide ligand $\mathrm{L}^{1} \mathrm{SSL}^{1}$ with different $\mathrm{Co}(\mathrm{II})$ and $\mathrm{Fe}(\mathrm{II})$ salts. Whereas the $\mathrm{Co}(\mathrm{II})$ disulfide compound is air-stable, the $\mathrm{Co}(\mathrm{III})$ thiolate compounds are slightly air-sensitive. The crystal structure of 3 showed the presence (with low occupancy factor) of a complex containing a mono-oxygenated sulfenate ligand, and crystallization of $\mathbf{2}$ in air after 8 weeks resulted in crystals of oxidized compound $\mathbf{2}_{\mathrm{Ox}}$ comprising a dioxygenated sulfinate ligand. ESI-MS spectra of solutions containing 3 taken after $2 \mathrm{~h}$ in air did not show any oxidation products, confirming that this oxidation process is very slow and thus that the effect on the redox studies is negligible. Using UV-vis spectroscopy, we showed that the addition of chloride anions to cobalt(III) compound 2 results in a redox interconversion reaction yielding cobalt(II) disulfide compound $\mathbf{1}_{\mathrm{Co}}$, whereas removal of the chloride anions from $\mathbf{1}_{\mathrm{Co}}$ regenerates compound 2. In 2001, the group of Itoh reported the synthesis of a $\mathrm{Cu}(\mathrm{II})$ thiolate compound from a similar disulfide ligand. ${ }^{20}$ The addition of chloride anions to this $\mathrm{Cu}(\mathrm{II})$ thiolate compound led to the redox interconversion reaction to the corresponding $\mathrm{Cu}(\mathrm{I})$ disulfide compound, whereas removal of the chloride anions resulted in the regeneration of the $\mathrm{Cu}$ (II) thiolate compound. In contrast, the group of Henkel reported a $\mathrm{Cu}(\mathrm{I})$ disulfide compound that upon addition of chloride ions resulted in the formation of a $\mathrm{Cu}(\mathrm{II})$ thiolate compound. ${ }^{15}$ Similarly, the group of Duboc recently reported a $\mathrm{Co}$ (III) thiolate compound that upon removal of chloride ions resulted in a $\mathrm{Co}$ (II) disulfide complex. ${ }^{24}$ Clearly, the formation of metal thiolate or disulfide compounds cannot be predicted based on the anions only.

For comparison the synthesis of the related iron(II) compounds has been investigated. Reaction of ligand $\mathrm{L}^{1} \mathrm{SSL}^{1}$ with $\mathrm{FeCl}_{2} \cdot 4 \mathrm{H}_{2} \mathrm{O}$ results in the formation of the iron(II) disulfide compound $\left[\mathrm{Fe}^{\mathrm{II}}\left(\mathrm{L}^{1} \mathrm{SSL}^{1}\right) \mathrm{Cl}_{4}\right]\left(\mathbf{1}_{\mathrm{Fe}}\right)$, showing a structure that is slightly different from that of $\left[\mathrm{Co}_{2}^{\mathrm{II}}\left(\mathrm{L}^{1} \mathrm{SSL}^{1}\right)\right.$ $\left.\mathrm{Cl}_{4}\right]\left(\mathbf{1}_{\mathrm{Co}}\right)$. However, instead of the expected $\mathrm{Fe}(\mathrm{III})$-thiolate compound similar to 2 , reaction of $\mathbf{1}_{\mathrm{Fe}}$ with $\mathrm{AgBF}_{4}$ did not give conclusive results, and reaction of ligand $\mathrm{L}^{1} \mathrm{SSL}^{1}$ with $\left[\mathrm{Fe}(\mathrm{MeCN})_{6}\right]\left(\mathrm{BF}_{4}\right)_{2}$ resulted in the formation of a fluoridebridged tetranuclear iron(II) compound. ${ }^{25}$ Thus, the redox interconversion in the iron compound appears to be more difficult despite the fact that one of the thioether sulfurs in $\mathbf{1}_{\mathrm{Fe}}$ is coordinating.

In order to understand the reactivity observed for our compounds, DFT calculations were employed to further explore the electronic structure of $\mathbf{1}_{\mathrm{Co}}, \mathbf{1}_{\mathrm{Fe}}, \mathbf{3}$, and the cationic part of $\mathbf{2}$. The obtained results show that $\mathbf{1}_{\mathrm{Co}}$ has the lowest energy with two high-spin $\mathrm{Co}$ (II) centers (two $S=3 / 2$ ions), consistent with the crystal structure and the observed effective magnetic moment, whereas low-spin $\mathrm{Co}(\mathrm{III})$ centers $(S=0)$ yield the lowest energy structures in compounds 2 and 3 , in agreement with the crystal data and the diamagnetic NMR spectra. Similarly, $\mathbf{1}_{\mathrm{Fe}}$ has the lowest energy with both iron centers in high-spin states $(S=2)$, in line with the crystal structure and the magnetic susceptibility in solution.

Combination of experimental results and DFT calculations confirm the formation of a low-spin $(S=0)$ mononuclear $\mathrm{Co}(\mathrm{III})$-thiolate compound in contrast to the dinuclear dithiolate-bridged structure reported for $\mathrm{Cu}(\mathrm{II})$ and the dinuclear $\mathrm{Co}(\mathrm{II})$ compounds with quartet-spin state (two $S$ $=3 / 2$ ions) reported by the group of Duboc. ${ }^{18,24}$ The antiferromagnetic interaction between the two $\mathrm{Cu}(\mathrm{II})$ ions or the strong antiferromagnetic coupling between two $S=3 / 2$ cobalt(II) ions reported by the group of Duboc are likely beneficial for the stabilization of the dinuclear compounds. Our computations show that antiferromagnetic coupling does not stabilize dinuclear cobalt(III) thiolate compounds 5 and $\mathbf{6}$. Formation of dinuclear cobalt(III) compound $\mathbf{5}$ from mononuclear 2 seemingly results in a slightly lower Gibbs free energy, which suggests that in solution 2 and 5 may be in equilibrium. However, the compound that crystallizes from the solution is mononuclear 2 , and the question remains why the cobalt(III) ions in our ligand $\mathrm{L}^{1} \mathrm{~S}^{-}$prefer a low-spin configuration in contrast to the intermediate spin occurring in the Duboc system.

The character of the HOMOs of compounds 2 and 3 and theoretical intermediates $\mathbf{2 a}, \mathbf{3 a}$, and $\mathbf{4}$ was investigated to explore the potential dependence of the electron distribution in the HOMO on the presence of different anions, as well as the potential transfer of electron density between cobalt and 
sulfur. The HOMO of these compounds has mainly character of $\mathrm{p}$ orbitals on sulfur and d orbitals on cobalt, and a small shift of the character of the HOMOs from $\mathrm{p}$ orbitals on sulfur to $d$ orbitals on cobalt is found upon substitution of the thiocyanate by chloride anions. Our computational investigation on the potential shift of electron density from sulfur to cobalt upon coordination of chloride anions were not conclusive to help understand the experimental finding of the formation of a $\mathrm{Co}$ (II) disulfide compound upon addition of chloride ions.

\section{SUMMARY AND CONCLUSIONS}

In this manuscript, we report the synthesis of low-spin mononuclear $\mathrm{Co}$ (III) thiolate compounds and high-spin dinuclear $\mathrm{Co}(\mathrm{II})$ and $\mathrm{Fe}(\mathrm{II})$ disulfide compounds from a disulfide ligand $\mathrm{L}^{1} \mathrm{SSL}^{1}$ in reaction with $\mathrm{Co}$ (II) and $\mathrm{Fe}$ (II) salts. It is shown that the redox interconversion of this $\mathrm{Co}$ (III) thiolate and the corresponding $\mathrm{Co}$ (II) disulfide compound is triggered by the addition or removal of chloride anions. DFT calculations show that the HOMO consists gradually more of the $d$ orbital on cobalt and less of the p orbital on sulfur when the thiocyanate molecules in the compound $\left[\mathrm{Co}^{\mathrm{III}}\left(\mathrm{L}^{1} \mathrm{~S}\right)\right.$ $\left.(\mathrm{NCS})_{2}\right]$ are substituted with chloride ions. This is the first example of a redox interconversion reaction between low-spin $\mathrm{Co}(\mathrm{III})$ thiolate and high-spin $\mathrm{Co}$ (II) disulfide compounds. Despite the new information that is gained including our computational studies, still more research needs to be done to predict accurately the conditions that trigger the redox interconversion reactions for metal thiolate and disulfide compounds.

\section{EXPERIMENTAL SECTION}

General Procedures. All the reagents were purchased from commercial sources and used as received unless noted otherwise. Dry acetonitrile and diethyl ether were obtained from a solvent dispenser (PureSolV 400), and methanol was acquired from commerical vendors and stored on $3 \AA$ molecular sieves. The synthesis of metal compounds was carried out using standard Schlenk-line techniques under a nitrogen atomsphere. ${ }^{1} \mathrm{H}$ NMR spectra were recorded on a Bruker 300 DPX spectrometer at room temperature. Mass spectra were recorded on a Finnigan Aqua mass spectrometer with electrospray ionization (ESI). IR spectra were acquired on a PerkinElmer UATR spectrum equipped with a single reflection diamond (scan range $400-4000 \mathrm{~cm}^{-1}$, resolution $4 \mathrm{~cm}^{-1}$ ). UV-vis spectra were collected using a transmission dip probe with variable path lengths and reflection probe on an Avantes Avaspec-2048 spectrometer with Avalight-DH-S-BAL light source. A WITEC alpha300R-Confocal Raman Imaging with the laser wavelength of $476 \mathrm{~nm}$ was used to record the Raman spectra, and all of the measurements were carried out under ambient conditions at room temperature. Elemental analyses were performed by the Microanalytical Laboratory Kolbe in Germany. Cyclic voltammetry (CV) was performed with an Autolab PGstat 10 potentiostat controlled by GPES4 software. A three-electrode system was used including an $\mathrm{Ag} /$ $\mathrm{AgCl}$ double junction reference electrode, a glassy carbon working electrode ( $3 \mathrm{~mm}$ diameter), and a $\mathrm{Pt}$ wire counter electrode in a solution containing $0.1 \mathrm{M} \mathrm{NBu}_{4} \mathrm{PF}_{6}$. In these conditions the $\mathrm{Fc} / \mathrm{Fc}^{+}$ couple was found to be located at $+0.428 \mathrm{~V}$ with a peak-to-peak separation of $91 \mathrm{mV}$ in acetonitrile. Potentials are given relative to the $\mathrm{Ag} / \mathrm{AgCl}$ electrode.

Single Crystal X-ray Crystallography. All reflection intensities were measured at $110(2) \mathrm{K}$ using a SuperNova diffractometer (equipped with Atlas detector) with Mo $\mathrm{K} \alpha$ radiation $(\lambda=0.71073$ $\AA$ ) under the program CrysAlisPro (version 1.171.36.32 Agilent Technologies, 2013 was used for $\mathbf{1}_{\mathrm{Co}}, \mathbf{2}_{\mathrm{Ox}}$ and $\mathbf{1}_{\mathrm{Fe}}$; version CrysAlisPro 1.171.39.29c, Rigaku OD, 2017 was used for compound 3 ). The same program was used to refine the cell dimensions and for data reduction. The structures were solved with the program SHELXS-2013 or SHELXS-2014/7 and were refined on $F^{2}$ with SHELXL-2013 or SHELXS-2014/7. ${ }^{36}$ Analytical numeric absorption correction based on a multifaceted crystal model or numerical absorption correction based on Gaussian integration over a multifaceted crystal model were applied using CrysAlisPro. The temperature of the data collection was controlled using the system Cryojet (manufactured by Oxford Instruments). The $\mathrm{H}$ atoms were placed at calculated positions using the instructions AFIX 23, AFIX 43, or AFIX 137 with isotropic displacement parameters having values 1.2 or $1.5 U_{\text {eq }}$ of the attached $\mathrm{C}$ atoms. The $\mathrm{H}$ atoms attached to $\mathrm{O} 1 \mathrm{~S}$ and $\mathrm{O} 2 \mathrm{~S}$ (lattice methanol solvent molecules) for $\mathbf{1}_{\mathrm{Fe}}$ were found from difference Fourier maps, and their coordinates were refined freely. The structures of $\mathbf{1}_{\mathrm{Co}}, \mathbf{2}_{\mathrm{Ox}} \mathbf{1}_{\mathrm{Fe}}$, and $\mathbf{3}$ are mostly ordered.

For $\mathbf{1}_{\mathrm{Fe}}$, the absolute configuration was established by anomalousdispersion effects in diffraction measurements on the crystal, and the Flack and Hooft parameters refine to 0.006(5) and 0.010(6), respectively. While finalizing the refinement of 3 , one residual electron density peak of $2.47 \mathrm{e}^{-} \AA^{-3}$ was found at ca. $1.46 \AA$ from S1. This peak is thought to be an oxygen atom, and its presence may result from the partial oxidation of $S 1$ occurring during the crystallization process. Its occupancy factor was set to refine freely, and its final value is $0.178(5)$. Another peak of $0.42 \mathrm{e}^{-} \AA^{-3}$ was found at ca. $1.12 \AA$ from S1. The nature of this peak is not entirely clear.

Density Functional Theory (DFT) Calculations. All calculations were performed with the Amsterdam Density Functional (ADF) program version $\mathrm{r} 47953,{ }^{37,38}$ using relativistic DFT at ZORA OPBE/TZ2P for geometry optimization and energies. ${ }^{39}$ Solvation in acetonitrile was simulated using the conductor-like screening model (COSMO).$^{40-43}$ All stationary points in the gas phase and in the condensed phase were verified to be minima on the potential energy surface (PES) through vibrational analysis. The energies of the singlet state of the $\mathrm{Cu}^{\mathrm{II}} / \mathrm{Co}^{\mathrm{III}} \mu$-thiolate complexes $\left(E^{S}\right)$ have been obtained from the unrestricted broken-symmetry singlet energies $\left(E^{\mathrm{BS}}\right)$ and the energy of the triplet $\left(E^{\mathrm{T}}\right)$ with the approximate projection method of Noodleman: $E^{\mathrm{S}}=2 E^{\mathrm{BS}}-E^{\mathrm{T}}$. 44,45

The Gibbs free energies $(\Delta G=\Delta H-T \Delta S)$ were evaluated with the following procedure. Enthalpies at $298.15 \mathrm{~K}$ and $1 \mathrm{~atm}\left(\Delta H_{298}\right)$ were calculated from electronic bond energies $(\Delta E)$ in the solvent and vibrational frequencies using standard thermochemistry relations for an ideal gas, according to ${ }^{46}$

$$
\begin{aligned}
\Delta H_{298}= & \Delta E+\Delta E_{\text {trans }, 298}+\Delta E_{\mathrm{rot}, 298}+\Delta E_{\mathrm{vib}, 0}+\Delta\left(\Delta E_{\mathrm{vib}, 0}\right)_{298} \\
& +\Delta(p V)
\end{aligned}
$$

Here, $\Delta E_{\text {trans,298, }} \Delta E_{\text {rot,298 }}$ and $\Delta E_{\mathrm{vib}, 0}$ are the differences between the two complexes in translational, rotational and zero-point vibrational energy, respectively; $\Delta\left(\Delta E_{\mathrm{vib}, 0}\right)_{298}$ is the change in the vibrational energy difference as one goes from 0 to $298.15 \mathrm{~K}$. The vibrational energy corrections are based on our frequency calculations in the gas phase. The molar work term $\Delta(p V)$ is $(\Delta n) R T$, with $n=0$. Thermal corrections for the electronic energy are neglected. The entropy $\Delta S$ was also obtained from the gas phase calculations. Most systems were optimized in $C_{1}$ symmetry. $\mathrm{CH}_{3} \mathrm{CN}$ was optimized with $C_{3 v}$ symmetry.

Synthesis of the Compounds. $\left[\mathrm{CO}_{2}^{\prime \prime}\left(\mathrm{L}^{1} S S L^{1}\right) \mathrm{Cl}_{4}\right]\left(1_{\mathrm{Co}}\right)$. Ligand $\mathrm{L}^{1} \mathrm{SSL}^{1}(107.0 \mathrm{mg}, 0.207 \mathrm{mmol})$ was dissolved in $3 \mathrm{~mL}$ of dry acetonitrile, and separately $\mathrm{CoCl}_{2} \cdot 6 \mathrm{H}_{2} \mathrm{O}(98.5 \mathrm{mg}, 0.414 \mathrm{mmol})$ was dissolved in $3 \mathrm{~mL}$ of dry acetonitrile. The two solutions were mixed resulting in a purple solution, which was stirred for about $30 \mathrm{~min}$. Then, $8 \mathrm{~mL}$ of diethyl ether was added, and a purple precipitate was obtained which was washed with diethyl ether $(5 \times 5 \mathrm{~mL})$. Yield: 99.1 $\mathrm{mg}, 0.13 \mathrm{mmol}, 64 \%$. Single crystals suitable for X-ray diffraction were obtained by slow vapor diffusion of diethyl ether into the acetonitrile solution containing the compound; single crystals were obtained after 2 days at room temperature. IR $\left(\mathrm{cm}^{-1}\right): 1606 \mathrm{~s}, 1571 \mathrm{w}, 1480 \mathrm{~m}, 1442 \mathrm{~s}$, $1092 \mathrm{w}, 1022 \mathrm{~m}, 766 \mathrm{vs}, 648 \mathrm{~m}, 478 \mathrm{w}$. ESI-MS found (calcd) for [M$\mathrm{Cl}]^{+} \mathrm{m} / z$ 740.8 (740.9). Elemental analysis calcd (\%) for $\mathrm{C}_{28} \mathrm{H}_{32} \mathrm{Cl}_{4} \mathrm{Co}_{2} \mathrm{~N}_{6} \mathrm{~S}_{2}+2 \mathrm{H}_{2} \mathrm{O}$ : C 41.40, $\mathrm{H}$ 4.47, $\mathrm{N}$ 10.3; found: C: $41.71, \mathrm{H}, 4.57, \mathrm{~N}, 9.80$. UV-vis (acetonitrile at $1 \mathrm{mM}[\mathrm{Co}]): \lambda_{\max }(\varepsilon$ 
in $\left.\mathrm{M}^{-1} \mathrm{~cm}^{-1}\right): 261 \mathrm{~nm}\left(4.6 \times 10^{3}\right), 524 \mathrm{~nm}\left(0.1 \times 10^{3}\right), 570 \mathrm{~nm}(0.1$ $\left.\times 10^{3}\right), 640 \mathrm{~nm}\left(0.1 \times 10^{3}\right)$.

$\left[\mathrm{CO}^{\prime \prime \prime}\left(\mathrm{L}^{1} \mathrm{~S}\right)(\mathrm{MeCN})_{2}\right]\left(\mathrm{BF}_{4}\right)_{2}(2)$. To a yellow solution of ligand $\mathrm{L}^{1} \mathrm{SSL}^{1}$ $(71.2 \mathrm{mg}, 0.138 \mathrm{mmol})$ in $4.6 \mathrm{~mL}$ of dry and degassed acetonitrile, solid $\left[\mathrm{Co}(\mathrm{MeCN})_{6}\right]\left(\mathrm{BF}_{4}\right)_{2}(131.7 \mathrm{mg}, 0.275 \mathrm{mmol})$ was added, resulting in a brown yellow solution. The acquired solution was stirred for $3 \mathrm{~h}$, and then the volume was reduced to $0.5 \mathrm{~mL}$. Addition of 15 $\mathrm{mL}$ of diethyl ether led to the formation of a yellow oil material. The obtained yellow oil material was washed with diethyl ether $(3 \times 15$ $\mathrm{mL}$ ). Yield: $103.0 \mathrm{mg}, 0.18 \mathrm{mmol}, 65 \%$. Single crystals of 2 could not be obtained, but from an acetonitrile solution of compound 2 kept in air, after 8 weeks crystals were obtained of the cobalt(III) sulfinate compound $\left[\mathrm{Co}^{\mathrm{III}}\left(\mathrm{L}^{1} \mathrm{SO}_{2}\right)(\mathrm{MeCN})_{2}\right]\left(\mathrm{BF}_{4}\right)_{2}\left(\mathbf{2}_{\mathrm{Ox}}\right) . \mathrm{IR}\left(\mathrm{cm}^{-1}\right): 1606 \mathrm{~m}$, $1481 \mathrm{w}, 1480 \mathrm{w}, 1444 \mathrm{w}, 1292 \mathrm{~m}, 1018 \mathrm{~s}, 764 \mathrm{~s}, 727 \mathrm{w}, 648 \mathrm{w}, 523 \mathrm{w}$, 476w. ${ }^{1} \mathrm{H}$ NMR $\left(300 \mathrm{MHz}\right.$, acetonitrile- $\left.d_{3}, \mathrm{RT}\right): \delta=8.39(2 \mathrm{H}, \mathrm{Py}-$ $\left.\mathrm{H}_{6}\right), 8.10\left(2 \mathrm{H}, \mathrm{Py}-\mathrm{H}_{4}\right), 7.56\left(4 \mathrm{H}, \mathrm{Py}-\mathrm{H}_{3}, \mathrm{Py}-\mathrm{H} 5\right), 5.02(2 \mathrm{H}, \mathrm{Py}-$ $\left.\mathrm{CH}_{2}\right), 4.34\left(2 \mathrm{H}, \mathrm{Py}-\mathrm{CH}_{2}\right), 3.12\left(\mathrm{~N}-\mathrm{CH}_{2}-\mathrm{CH}_{2}-\mathrm{S}\right), 2.55$ (proton probably from the coordinated acetonitrile), $2.09\left(\mathrm{H}_{2} \mathrm{O}\right), 1.94$ (MeCN). ESI-MS found (calcd) for $1 / 2\left[\mathrm{M}-2\left(\mathrm{BF}_{4}\right)\right]^{2+} \mathrm{m} / z 199.8$ (199.5). UV-vis (acetonitrile at $1 \mathrm{mM}[\mathrm{Co}]): \lambda_{\max }\left(\varepsilon\right.$ in $\left.\mathrm{M}^{-1} \mathrm{~cm}^{-1}\right)$ : $262 \mathrm{~nm}\left(8.1 \times 10^{3}\right), 287 \mathrm{~nm}\left(6.9 \times 10^{3}\right), 442 \mathrm{~nm}\left(0.4 \times 10^{3}\right)$.

$\left[\mathrm{Co}^{\prime \prime \prime}\left(\mathrm{L}^{1} \mathrm{~S}\right)(\mathrm{NCS})_{2}\right]$ (3). Ligand $\mathrm{L}^{1} \mathrm{SSL}^{1}$ (103.9 mg, $\left.0.201 \mathrm{mmol}\right)$ was dissolved in $5 \mathrm{~mL}$ of dry and degassed acetonitrile, to which solid $\mathrm{Co}(\mathrm{NCS})_{2}(70.3 \mathrm{mg}, 0.401 \mathrm{mmol})$ was added, resulting in a dark brown solution. The solution was stirred for $3 \mathrm{~h}$ at room temperature, after which the volume was reduced to $2 \mathrm{~mL}$. Addition of $20 \mathrm{~mL}$ of diethyl ether resulted in the formation of a dark brown powder. The acquired powder was washed with diethyl ether $(3 \times 10 \mathrm{~mL})$. Yield: $120.0 \mathrm{mg}, 0.28 \mathrm{mmol}, 70 \%$. Single crystals suitable for X-ray diffraction were grown by slow vapor diffusion of isopropyl ether into the acetonitrile solution containing the compound; single crystals were obtained after approximately 3 weeks at room temperature. ${ }^{1} \mathrm{H}$ NMR $\left(300 \mathrm{MHz}\right.$, acetonitrile- $\left.d_{3}, \mathrm{RT}\right): \delta=8.42\left(\mathrm{~d}, 2 \mathrm{H}, \mathrm{Py}-\mathrm{H}_{6}\right), 8.01$ $\left(\mathrm{t}, 2 \mathrm{H}, \mathrm{Py}-\mathrm{H}_{4}\right), 7.59\left(\mathrm{t}, 2 \mathrm{H}, \mathrm{Py}-\mathrm{H}_{3}\right), 7.45\left(\mathrm{~d}, 2 \mathrm{H}, \mathrm{Py}-\mathrm{H}_{5}\right), 4.98(\mathrm{~d}$, $\left.2 \mathrm{H}, \mathrm{Py}-\mathrm{CH}_{2}\right), 4.22\left(\mathrm{~d}, 2 \mathrm{H}, \mathrm{Py}-\mathrm{CH}_{2}\right), 3.65\left(\mathrm{~d}, 2 \mathrm{H}, \mathrm{S}-\mathrm{CH}_{2}-\mathrm{CH}_{2}\right)$, $2.95\left(\mathrm{t}, 2 \mathrm{H}, \mathrm{S}-\mathrm{CH}_{2}-\mathrm{CH}_{2}\right), 2.14\left(\mathrm{H}_{2} \mathrm{O}\right), 1.94(\mathrm{MeCN}) .{ }^{13} \mathrm{C} \mathrm{NMR}$ $\left(300 \mathrm{MHz}\right.$, acetonitrile- $\left.d_{3}, \mathrm{RT}\right): \delta=30.67(\mathrm{C}-\mathrm{S}), 67.95(\mathrm{Py}-\mathrm{C}-\mathrm{N})$, $70.82\left(\mathrm{~N}-\mathrm{CH}_{2}-\mathrm{CH}_{2}-\mathrm{S}\right), 121.88\left(\mathrm{Py}-\mathrm{C}_{5}\right), 125.60\left(\mathrm{Py}-\mathrm{C}_{3}\right), 139.66$ $\left(\mathrm{Py}-\mathrm{C}_{4}\right), 152.37\left(\mathrm{Py}-\mathrm{C}_{6}\right), 162.11\left(\mathrm{Py}-\mathrm{C}_{2}\right)$. ESI-MS found (calcd) for $[\mathrm{M}-\mathrm{NCS}]^{+} \mathrm{m} / \mathrm{z} 375.3$ (375.1). IR $\left(\mathrm{cm}^{-1}\right)$ : 2106vs, 2090s, $1608 \mathrm{~m}, 1478 \mathrm{~m}, 1445 \mathrm{~s}, 1304 \mathrm{~m}, 1277 \mathrm{~m}, 1229 \mathrm{w}, 1156 \mathrm{w}, 1108 \mathrm{w}$, $1054 \mathrm{~m}, 1017 \mathrm{w}, 993 \mathrm{w}, 952 \mathrm{~m}, 895 \mathrm{~m}, 821 \mathrm{~m}, 752 \mathrm{vs}, 786 \mathrm{~s}, 652 \mathrm{~m}, 557 \mathrm{w}$, $532 \mathrm{~m}, 479 \mathrm{~s}$. Elemental analysis calcd $(\%)$ for $\mathrm{C}_{16} \mathrm{H}_{16} \mathrm{CoN}_{5} \mathrm{~S}_{3}$ : C 44.34, H 3.72, N 16.16; found: C 44.19, H, 3.87, N, 15.94. UV-vis (acetonitrile at $1 \mathrm{mM}[\mathrm{Co}]): \lambda_{\max }\left(\varepsilon\right.$ in $\left.\mathrm{M}^{-1} \mathrm{~cm}^{-1}\right): 238 \mathrm{~nm}(6.7 \times$ $\left.10^{3}\right), 279 \mathrm{~nm}\left(8.5 \times 10^{3}\right), 325 \mathrm{~nm}\left(4.8 \times 10^{3}\right), 515 \mathrm{~nm}\left(0.7 \times 10^{3}\right)$.

$\left[\mathrm{Fe}_{2}^{\prime \prime}\left(\mathrm{L}^{1} \mathrm{SSL}^{1}\right) \mathrm{Cl}_{4}\right]\left(1_{\mathrm{Fe}}\right)$. Ligand $\mathrm{L}^{1} \mathrm{SSL}^{1}(77.7 \mathrm{mg}, 0.150 \mathrm{mmol})$ was dissolved in $6 \mathrm{~mL}$ of dry and degassed methanol to which $60.0 \mathrm{mg}$ $(0.30 \mathrm{mmol})$ of $\mathrm{FeCl}_{2} \cdot 4 \mathrm{H}_{2} \mathrm{O}$ was added, resulting in a green-yellow solution. The solution was stirred for another $2 \mathrm{~h}$ at room temperature, after which $20 \mathrm{~mL}$ of dry and degassed diethyl ether was added, yielding a yellow precipitate. The obtained precipitate was filtered and washed with diethyl ether $(4 \times 15 \mathrm{~mL})$. Yield: $59.3 \mathrm{mg}$, $0.07 \mathrm{mmol}, 62 \%$. Single crystals suitable for X-ray structure determination were grown by slow vapor diffusion of diethyl ether into a methanol solution of this compound; single crystals were obtained after 4 days at room temperature. IR $\left(\mathrm{cm}^{-1}\right): 1604 \mathrm{~s}, 1571 \mathrm{w}$, $1479 \mathrm{w}, 1442 \mathrm{~s}, 1291 \mathrm{w}, 1155 \mathrm{w}, 1088 \mathrm{~m}, 1052 \mathrm{~m}, 1019 \mathrm{~s}, 764 \mathrm{vs}, 725 \mathrm{w}$, $642 \mathrm{w}$. ESI-MS found (calcd) for $1 / 2[\mathrm{M}-2 \mathrm{Cl}]^{2+} \mathrm{m} / z 349.1$ (349.0). Elemental analysis calcd (\%) for $\mathrm{C}_{28} \mathrm{H}_{32} \mathrm{Cl}_{4} \mathrm{Fe}_{2} \mathrm{~N}_{6} \mathrm{~S}_{2}+3 \mathrm{H}_{2} \mathrm{O}$ : C 40.80, $\mathrm{H} 4.65, \mathrm{~N}$ 10.20; found: C 40.32, H 4.32, N 9.87. UV-vis (methanol at $1 \mathrm{mM}[\mathrm{Fe}]): \lambda_{\max }\left(\varepsilon\right.$ in $\left.\mathrm{M}^{-1} \mathrm{~cm}^{-1}\right): 256 \mathrm{~nm}\left(8.6 \times 10^{3}\right), 313 \mathrm{~nm}$ $\left(1.0 \times 10^{3}\right), 390 \mathrm{~nm}\left(1.8 \times 10^{3}\right)$.

\section{ASSOCIATED CONTENT}

\section{S Supporting Information}

The Supporting Information is available free of charge on the ACS Publications website at DOI: 10.1021/acs.inorgchem.8b00549.
Raman, UV-vis, ${ }^{1} \mathrm{H}$ NMR, ${ }^{13} \mathrm{C}$ NMR, and ESI-MS spectra and the cyclic voltammograms of the compounds; Cartesian coordinates of the calculated structures, calculated energies and plots of the HOMOs (PDF)

\section{Accession Codes}

CCDC 1496381, 1496385, 1827153, and 1850287 contain the supplementary crystallographic data for this paper. These data can be obtained free of charge via www.ccdc.cam.ac.uk/ data_request/cif, or by emailing data_request@ccdc.cam.ac. uk, or by contacting The Cambridge Crystallographic Data Centre, 12 Union Road, Cambridge CB2 1EZ, UK; fax: +44 1223336033.

\section{AUTHOR INFORMATION}

\section{Corresponding Authors}

*E-mail: c.fonseca.guerra@lic.leidenuniv.nl.

*E-mail: bouwman@lic.leidenuniv.nl.

\section{ORCID}

Célia Fonseca Guerra: 0000-0002-2973-5321

Elisabeth Bouwman: 0000-0001-7762-3968

\section{Notes}

The authors declare no competing financial interest.

\section{ACKNOWLEDGMENTS}

F.J. and L.J. gratefully acknowledge the China Scholarship Council (CSC) for a personal grant (Nos. 201406890012 and 201406890016). The Netherlands Organization for Scientific Research (NWO-CW) is acknowledged for the financial support. We thank Mr. Anne Geert Volbeda, Jos van Brussel and Wim Jesse for ESI-MS analysis, Mr. Fons Lefeber for assistance with the NMR spectrometers. Dr. G. F. Schneider is acknowledged for use of the Raman spectrometer.

\section{REFERENCES}

(1) Jacob, C.; Giles, G. L.; Giles, N. M.; Sies, H. Sulfur and selenium: The role of oxidation state in protein structure and function. Angew. Chem., Int. Ed. 2003, 42, 4742-4758.

(2) Iwata, S.; Ostermeier, C.; Ludwig, B.; Michel, H. Structure at 2.8-Angstrom Resolution of Cytochrome c Oxidase from Paracoccus Denitrificans. Nature 1995, 376, 660-669.

(3) Kovacs, J. A. Tuning the Relative Stability and Reactivity of Manganese Dioxygen and Peroxo Intermediates via Systematic Ligand Modification. Acc. Chem. Res. 2015, 48, 2744-2753.

(4) Paulsen, C. E.; Carroll, K. S. Cysteine-mediated redox signaling: chemistry, biology, and tools for discovery. Chem. Rev. 2013, 113, 4633-4679.

(5) Lamb, A. L.; Torres, A. S.; O’Halloran, T. V.; Rosenzweig, A. C. Heterodimeric structure of superoxide dismutase in complex with its metallochaperone. Nat. Struct. Biol. 2001, 8, 751-755.

(6) Palumaa, P.; Kangur, L.; Voronova, A.; Sillard, R. Metal-binding mechanism of Cox17, a copper chaperone for cytochrome $c$ oxidase. Biochem. J. 2004, 382, 307-314.

(7) Arnér, E. S.; Holmgren, A. Physiological functions of thioredoxin and thioredoxin reductase. Eur. J. Biochem. 2000, 267, 6102-6109.

(8) Banci, L.; Bertini, I.; Cavallaro, G.; Ciofi-Baffoni, S. Seeking the determinants of the elusive functions of Sco proteins. FEBS J. 2011, 278, 2244-2262.

(9) Cawthorn, T. R.; Poulsen, B. E.; Davidson, D. E.; Andrews, D.; Hill, B. C. Probing the kinetics and thermodynamics of copper(II) binding to Bacillus subtilis Sco, a protein involved in the assembly of the $\mathrm{Cu}_{\mathrm{A}}$ center of cytochrome $\mathrm{c}$ oxidase. Biochemistry 2009, 48, $4448-4454$. 
(10) Meloni, G.; Sonois, V.; Delaine, T.; Guilloreau, L.; Gillet, A.; Teissié, J.; Faller, P.; Vašák, M. Metal swap between $\mathrm{Zn}_{7}$-metallothionein-3 and amyloid- $\beta-\mathrm{Cu}$ protects against amyloid- $\beta$ toxicity. Nat. Chem. Biol. 2008, 4, 366-372.

(11) Pedersen, J. T.; Hureau, C.; Hemmingsen, L.; Heegaard, N. H.; Østergaard, J.; Vašák, M.; Faller, P. Rapid Exchange of Metal between $\mathrm{Zn}_{7}-$ Metallothionein-3 and Amyloid- $\beta$ Peptide Promotes AmyloidRelated Structural Changes. Biochemistry 2012, 51, 1697-1706.

(12) Houser, R. P.; Young, V. G.; Tolman, W. B. A thiolate-bridged, fully delocalized mixed-valence dicopper (I, II) complex that models the $\mathrm{Cu}_{\mathrm{A}}$ biological electron-transfer site. J. Am. Chem. Soc. 1996, 118, 2101-2102.

(13) Houser, R. P.; Halfen, J. A.; Young, V. G., Jr; Blackburn, N. J.; Tolman, W. B. Structural Characterization of the First Example of a Bis ( $\mu$-thiolato) dicopper(II) Complex. Relevance to Proposals for the Electron Transfer Sites in Cytochrome c Oxidase and Nitrous Oxide Reductase. J. Am. Chem. Soc. 1995, 117, 10745-10746.

(14) Itoh, S.; Nagagawa, M.; Fukuzumi, S. Fine tuning of the interaction between the copper(I) and disulfide bond. Formation of a bis(mu-thiolato)dicopper(II) complex by reductive cleavage of the disulfide bond with copper(I). J. Am. Chem. Soc. 2001, 123, 40874088 .

(15) Neuba, A.; Haase, R.; Meyer-Klaucke, W.; Flörke, U.; Henkel, G. A Halide-Induced Copper(I) Disulfide/Copper(II) Thiolate Interconversion. Angew. Chem., Int. Ed. 2012, 51, 1714-1718.

(16) Ording-Wenker, E. C.; van der Plas, M.; Siegler, M. A.; Fonseca Guerra, C.; Bouwman, E. Protonation of a Biologically Relevant CuII $\mu$-Thiolate Complex: Ligand Dissociation or Formation of a Protonated CuI Disulfide Species? Chem. - Eur. J. 2014, 20, 16913-16921.

(17) Ording-Wenker, E. C.; Siegler, M. A.; Bouwman, E. Coordination of new disulfide ligands to $\mathrm{Cu}^{\mathrm{I}}$ and $\mathrm{Cu}^{\mathrm{II}}$ : Does a $\mathrm{Cu}^{\mathrm{II}}$ $\mu$-thiolate complex form? Inorg. Chim. Acta 2015, 428, 193-202.

(18) Ording-Wenker, E. C.; van der Plas, M.; Siegler, M. A.; Bonnet, S.; Bickelhaupt, F. M.; Fonseca Guerra, C.; Bouwman, E. Thermodynamics of the $\mathrm{Cu}^{\mathrm{II}} \mu$-Thiolate and $\mathrm{Cu}^{\mathrm{I}}$ Disulfide Equilibrium: A Combined Experimental and Theoretical Study. Inorg. Chem. 2014, 53, 8494-8504.

(19) Thomas, A. M.; Lin, B. L.; Wasinger, E. C.; Stack, T. D. P. Ligand Noninnocence of Thiolate/Disulfide in Dinuclear Copper Complexes: Solvent-Dependent Redox Isomerization and ProtonCoupled Electron Transfer. J. Am. Chem. Soc. 2013, 135, 1891218919 .

(20) Ueno, Y.; Tachi, Y.; Itoh, S. Interconversion between bis ( $\mu$ thiolato) dicopper(II) and disulfide-bridged dicopper(I) complexes mediated by chloride ion. J. Am. Chem. Soc. 2002, 124, 12428-12429.

(21) Ohta, T.; Tachiyama, T.; Yoshizawa, K.; Yamabe, T.; Uchida, T.; Kitagawa, T. Synthesis, Structure, and $\mathrm{H}_{2} \mathrm{O}_{2}$-Dependent Catalytic Functions of Disulfide-Bridged Dicopper(I) and Related ThioetherCopper(I) and Thioether-Copper(II) Complexes. Inorg. Chem. 2000, 39, 4358-4369.

(22) Okamoto, S.; Eltis, L. D. The biological occurrence and trafficking of cobalt. Metallomics 2011, 3, 963-970.

(23) Kovacs, J. A. Synthetic analogues of cysteinate-ligated nonheme iron and non-corrinoid cobalt enzymes. Chem. Rev. 2004, 104, $825-848$.

(24) Gennari, M.; Gerey, B.; Hall, N.; Pécaut, J.; Collomb, M. N.; Rouzières, M.; Clérac, R.; Orio, M.; Duboc, C. A Bio-Inspired Switch Based on Cobalt(II) Disulfide/Cobalt(III) Thiolate Interconversion. Angew. Chem., Int. Ed. 2014, 53, 5318-5321.

(25) Jiang, F.; Siegler, M. A.; Bouwman, E. A Tetranuclear FluoridoBridged Iron Compound: Fluoride Abstraction from the Tetrafluoridoborate Anion. Inorg. Chem. Commun. 2018, 94, 53-56.

(26) Evans, D. 400. The determination of the paramagnetic susceptibility of substances in solution by nuclear magnetic resonance. J. Chem. Soc. 1959, 2003-2005.

(27) Bain, G. A.; Berry, J. F. Diamagnetic corrections and Pascal's constants. J. Chem. Educ. 2008, 85, 532.
(28) Van Wart, H. E.; Lewis, A.; Scheraga, H. A.; Saeva, F. D. Disulfide bond dihedral angles from Raman spectroscopy. Proc. Natl. Acad. Sci. U. S. A. 1973, 70, 2619-2623.

(29) Addison, A. W.; Rao, T. N.; Reedijk, J.; van Rijn, J.; Verschoor, G. C. Synthesis, structure, and spectroscopic properties of copper (II) compounds containing nitrogen-sulphur donor ligands; the crystal and molecular structure of aqua [1,7-bis (N-methylbenzimidazol-2'yl)-2, 6-dithiaheptane] copper (II) perchlorate. J. Chem. Soc., Dalton Trans. 1984, 1349-1356.

(30) Widger, L. R.; Jiang, Y.; McQuilken, A. C.; Yang, T.; Siegler, M. A.; Matsumura, H.; Moënne-Loccoz, P.; Kumar, D.; De Visser, S. P.; Goldberg, D. P. Thioether-ligated iron(II) and iron(III)-hydroperoxo/alkylperoxo complexes with an $\mathrm{H}$-bond donor in the second coordination sphere. Dalton Trans. 2014, 43, 7522-7532.

(31) Sellmann, D.; Peters, K. P.; Heinemann, F. W. New Pentadentate Carboxylate-Derivatized Sulfur Ligands Affording Water Soluble Iron Complexes with $\left[\mathrm{Fe}\left(\mathrm{NS}_{4}\right)\right]$ Cores that Bind Small Molecules (CO, $\mathrm{NO}, \mathrm{PMe}_{3}$ ) as Co-Ligands. Eur. J. Inorg. Chem. 2004, 2004, 581-590.

(32) Das, U. K.; Daifuku, S. L.; Gorelsky, S. I.; Korobkov, I.; Neidig, M. L.; Le Roy, J. J.; Murugesu, M.; Baker, R. T. Mononuclear, Dinuclear, and Trinuclear Iron Complexes Featuring a New Monoanionic SNS Thiolate Ligand. Inorg. Chem. 2016, 55, 987-997.

(33) Lever, A. B. P. Inorganic Electronic Spectroscopy, 2nd ed.; Elsevier: Amsterdam, the Netherlands, 1968.

(34) Coe, B. J.; Harris, J. A.; Brunschwig, B. S.; Asselberghs, I.; Clays, K.; Garín, J.; Orduna, J. Three-dimensional nonlinear optical chromophores based on metal-to-ligand charge-transfer from ruthenium (II) or iron (II) centers. J. Am. Chem. Soc. 2005, 127, 13399-13410.

(35) Neuba, A.; Haase, R.; Meyer-Klaucke, W.; Flörke, U.; Henkel, G. A Halide-Induced Copper(I) Disulfide/Copper(II) Thiolate Interconversion. Angew. Chem., Int. Ed. 2012, 51, 1714-1718.

(36) Sheldrick, G. M. A short history of SHELX. Acta Crystallogr., Sect. A: Found. Crystallogr. 2008, 64, 112-122.

(37) te Velde, G.; Bickelhaupt, F. M.; Baerends, E. J.; Fonseca Guerra, C.; Van Gisbergen, S. J. A.; Snijders, J. G.; Ziegler, T. Chemistry with ADF. J. Comput. Chem. 2001, 22, 931-967.

(38) http://www.scm.com/.

(39) Swart, M.; Ehlers, A. W.; Lammertsma, K. Performance of the OPBE exchange-correlation functional. Mol. Phys. 2004, 102, 24672474.

(40) Klamt, A. Conductor-like Screening Model for Real Solvents: A New Approach to the Quantitative Calculation of Solvation Phenomena. J. Phys. Chem. 1995, 99, 2224-2235.

(41) Klamt, A.; Schuurmann, G. COSMO: a new approach to dielectric screening in solvents with explicit expressions for the screening energy and its gradient. J. Chem. Soc., Perkin Trans. 2 1993, 799-805.

(42) Pye, C. C.; Ziegler, T. An implementation of the conductor-like screening model of solvation within the Amsterdam density functional package. Theor. Chem. Acc. 1999, 101, 396-408.

(43) Swart, M.; Roesler, E.; Bickelhaupt, F. M. Proton affinities in water of maingroup-element Hydrides - Effects of hydration and methyl substitution. Eur. J. Inorg. Chem. 2007, 2007, 3646-3654.

(44) Noodleman, L. Valence bond description of antiferromagnetic coupling in transition metal dimers. J. Chem. Phys. 1981, 74, 57375743.

(45) Noodleman, L.; Baerends, E. J. Electronic structure, magnetic properties, ESR, and optical spectra for 2-iron ferredoxin models by LCAO-X.alpha. valence bond theory. J. Am. Chem. Soc. 1984, 106, 2316-2327.

(46) Jensen, F. Introduction to Computational Chemistry, 2nd ed.; Wiley: Chichester, West Sussex, U.K., 2006. 